\title{
Impact of storms and dense water cascading on shelf-slope exchanges in the Gulf of Lion (NW Mediterranean)
}

\author{
C. Ulses, ${ }^{1}$ C. Estournel, ${ }^{1}$ J. Bonnin, ${ }^{2}$ X. Durrieu de Madron, ${ }^{2}$ and P. Marsaleix ${ }^{1}$ \\ Received 3 July 2006; revised 1 April 2007; accepted 24 September 2007; published 13 February 2008.
}

[1] In situ observations of ocean temperature, salinity, density and current collected from November 2003 to May 2004 in the Gulf of Lion were combined with numerical modeling in order to better understand the mechanisms and forcing conditions that control shelfslope exchanges during autumn and winter times. Outputs from a 3-D coastal circulation model revealed that marine storms (and related processes) and dense water cascading were the two major mechanisms controlling shelf-slope exchanges. Marine storms induced accumulation of seawater along the coast, generated a strong cyclonic circulation on the shelf, and caused downwelling in submarine canyons that facilitated export of shelf water. During fall, because of strong water column stratification at that time, the depth of export remained shallow. In winter, the destratification together with the density increase of shelf water, due to the cooling effect of strong and cold northerly winds, enabled shelf water to plunge down the slope. The results of this study thus highlighted the importance of marine storms for shelf-slope exchanges, particularly during winter mixed conditions when they reinforced the cascading of dense water.

Citation: Ulses, C., C. Estournel, J. Bonnin, X. Durrieu de Madron, and P. Marsaleix (2008), Impact of storms and dense water cascading on shelf-slope exchanges in the Gulf of Lion (NW Mediterranean), J. Geophys. Res., 113, C02010, doi:10.1029/2006JC003795.

\section{Introduction}

[2] The continental margin, strongly influenced by terrestrial input and with its high productivity, is an important source of organic matter for the deep ocean. The quantification of the fluxes of water, and of particulate and dissolved matter originating from the coastal zone, reaching the slope or the abyssal plain, is therefore fundamental for the understanding of the marine biogeochemical cycles, the prediction of the consequences of climatic change and other anthropogenic perturbations. One of the most critical issues in this quantification is the identification and understanding of the principal processes controlling shelf-slope exchanges.

[3] Previous studies on shelf-slope exchanges (e.g., SEEP, ECOMARGE, OMEX) have shown that fluxes from the shelf to the slope are highly variable and related to various mechanisms forced by tides, winds, general circulation, topographical features, internal motions or a combination of two or more of these parameters. A scaling of the numerous physical mechanisms involved in shelf-slope exchanges was proposed by Huthnance [1995], but effective quantifications of their fluxes are scarce. Furthermore,

\footnotetext{
${ }^{1}$ Pole d'Océanographie Côtière, Laboratoire d'Aérologie, UMR 5560, Centre National de la Recherche Scientifique-Université Paul Sabatier, Toulouse, France.

${ }^{2}$ Centre de Formation et de Recherche sur l'Environnement Marin, Centre National de la Recherche Scientifique-Université de Perpignan, Perpignan, France.
}

Copyright 2008 by the American Geophysical Union. 0148-0227/08/2006JC003795 the question of the interaction between exchange processes, Does the total export correspond to the linear combination of individual mechanisms or are the different mechanisms amplified by one another? is still open.

[4] Recent observations made in the Gulf of Lion (NW Mediterranean) have highlighted the impact of dense water cascading and marine storms on the shelf-slope exchanges and provided some elements of response on the interaction between these two mechanisms. Cascading of dense water from the shelf has been observed in various areas [e.g., Ivanov et al., 2004; Vilibić et al., 2004; Estournel et al., 2005] but mass fluxes have seldom been quantified. In the Gulf of Lion, dense shelf water cascading appears as a predominant mechanism, controlling both the annual and interannual variability of the shelf water export during winter with flows of about $0.2 \mathrm{~Sv}$ [Béthoux et al., 2002; Dufau-Julliand et al., 2004; Guarracino et al., 2006].

[5] Several studies have emphasized the importance of extreme episodic events driven by meteorological conditions on the variability and intensity of shelf-slope exchanges. The impact of storms or typhoons has been evaluated in different regions such as the shelf off Washington State [e.g., Sternberg and McManus, 1972], the western Iberian margin [Vitorino et al., 2002], the northwestern Mediterranean [Skliris et al., 2004] or the shelf off southern Taiwan [Liu et al., 2006]. Extreme marine storms on the Gulf of Lion are rare, and major questions remain unanswered on the quantitative impact of such short and particularly intense events on the export of shelf water to the deep ocean. 
[6] The present paper assesses the impact of marine storms, high riverine discharges and dense shelf water cascading on the variability on the shelf-slope exchanges in the Gulf of Lion. It combines extensive field observations with 3-D modeling and reveals that severe marine storms largely enhanced shelf water export, and strongly influenced dense water formation and cascading during wintertime. The observations were obtained within the framework of a study focusing on the hydrodynamic and sedimentary processes linked to river floods and marine storms. This study was part of a large European program Eurostrataform [Mienert et al., 2004] which aimed at better understanding the fate of riverborne particles from the shelf down to the deep sea, and how they form the sedimentary strata.

[7] This paper is divided as follows: background information on the study area and description of the main forcing mechanisms are given in section 2. The hydrodynamic model and sampling strategy are presented in section 3. Field observations and validation of model outputs are then described in sections 4.1 and 4.2, and the main controlling parameters of shelf-slope exchanges over the study period are discussed afterward (sections 4.3 to 4.5 ) with focus on fall and winter marine storms and their interaction with dense water cascading. Finally, in section 4.6, the shelfslope exchanges of seawater during the major meteorological events are estimated.

\section{General Setting}

\subsection{Study Area}

[8] The Gulf of Lion is a river-dominated continental margin located in the western Mediterranean basin between $42^{\circ} \mathrm{N}, 3^{\circ} \mathrm{E}$ and $43^{\circ} \mathrm{N}, 6^{\circ} \mathrm{E}$. The crescent shaped continental shelf is fairly broad (up to $80 \mathrm{~km}$ ) for a Mediterranean margin, and its continental slope is incised by numerous submarine canyons (Figure 1). The Gulf of Lion is bounded to the southwest by the Cap Creus where the shelf narrows to a few kilometers.

[9] From a hydrodynamic point of view, the Gulf of Lion is a rather complex region where the major physical forcing factors are the general circulation (Northern Current), the various wind regimes and the fresh water discharge from rivers [Millot, 1990].

[10] The Northern Current that flows along the continental slope is part of the cyclonic circulation of the western Mediterranean basin. The core of this geostrophic current is several hundreds of meters thick and primarily composed of Modified Atlantic Water (upper $150 \mathrm{~m}$ ) and Levantine Intermediate Water deeper down. Furthermore, it forms a density front that separates the continentally influenced shelf water from the more saline open sea water. It constrains the shelf circulation and so influences shelf-slope exchanges.

[11] Strong winds over the Gulf of Lion are frequent. Offshore winds are constrained by the regional topography: the Tramontane is a northwesterly wind channeled by the Naurouze passage between the Pyrenees and the Massif Central whereas the Mistral is a northerly wind channeled by the Rhone River valley. According to wind data collected by Météo-France (French meteorological office) over the last 30 years, Mistral and Tramontane with speeds higher than $10 \mathrm{~m} \mathrm{~s}^{-1}$ occurred $28 \%$ and $41 \%$ of the time, respectively. Windy episodes can last up to one month. The Tramontane promotes local downwelling along the western coastline while the Mistral induces local upwelling along the northern coastline [Millot, 1990]. Because of a reduced fetch, they both generate relatively small waves (significant wave height $<2 \mathrm{~m}$, peak period $<6 \mathrm{~s}$ ) on the inner shelf. These cold and dry winds have a substantial cooling effect in winter and are responsible for dense water formation.

[12] Conversely, southeasterly and easterly marine wind events with speeds higher than $10 \mathrm{~m} \mathrm{~s}^{-1}$ are rare (less than $6 \%$ of the time) and brief (typically less than $3 \mathrm{~d}$ ). They are associated with large swells and a significant rise in the sea level on the coast as a consequence of shoreward water transport and low atmospheric pressure during these events [Ferré et al., 2005; Guillén et al., 2006].

[13] Finally, fresh water discharge in the Gulf of Lion originates mainly from the Rhone River although several other smaller rivers may also deliver substantial amounts of fresh water occasionally. The highest river discharge periods are generally found in spring and fall.

\subsection{Dense Water Cascading in the Gulf of Lion}

[14] The Gulf of Lion is one of the regions in the world where deep water formation and convection occur during the winter season. Open-ocean deep convection and deep water formation are known to occur on the continental rise as a result of the doming of isopycnals toward the surface at the center of the northwestern Mediterranean gyre, the uplift of the Levantine Intermediate Water salinity maximum into depths shallow enough to be exposed to entrainment with the mixed layer, and wintry cooling and evaporation of surface water caused by cold, dry northerly winds [MEDOC Group, 1970]. Deep Western Mediterranean Water has typical thermohaline characteristics of $\mathrm{T}=12.75-$ $12.82^{\circ} \mathrm{C} ; \mathrm{S}=38.43-38.47$; density $=29.10-29.12 \mathrm{~kg} \mathrm{~m}^{-3}$ [Béthoux et al., 2002]. The term "density" refers here and throughout the paper to potential density anomaly to ease the reading.

[15] Dense water formation also occurs on the shelf during wintertime. Despite the gain of buoyancy induced by fresh water inputs from rivers, shallow shelf waters get very cold, become denser than the offshore waters, and sink. After spreading on the shelf, dense water flows down the continental slope via the submarine canyons until it reaches its hydrostatic equilibrium level. Dufau-Julliand et al. [2004] showed that dense water preferentially spread over the western part of the Gulf of Lion's shelf and finally escaped at its southwestern end.

[16] Continuous temperature monitoring conducted since 1993 in the lower part of the Lacaze-Duthiers Canyon has revealed an annual recurrence of cold shelf water overflow, but with a strong interannual variation of its characteristics [Durrieu de Madron et al., 2005]. From hydrological surveys carried out during the winters 1969 and 1971, Fieux [1974] and Person [1974] traced dense water cascading in the Lacaze-Duthiers Canyon down to 800 and $350 \mathrm{~m}$, respectively. Further evidence was gained during winter 1995 by Lapouyade and Durrieu de Madron [2001] at the same location. They observed a cascade in its final stage with a large tongue of cold water escaping the shelf and reaching its neutral density level around $170 \mathrm{~m}$ depth. 


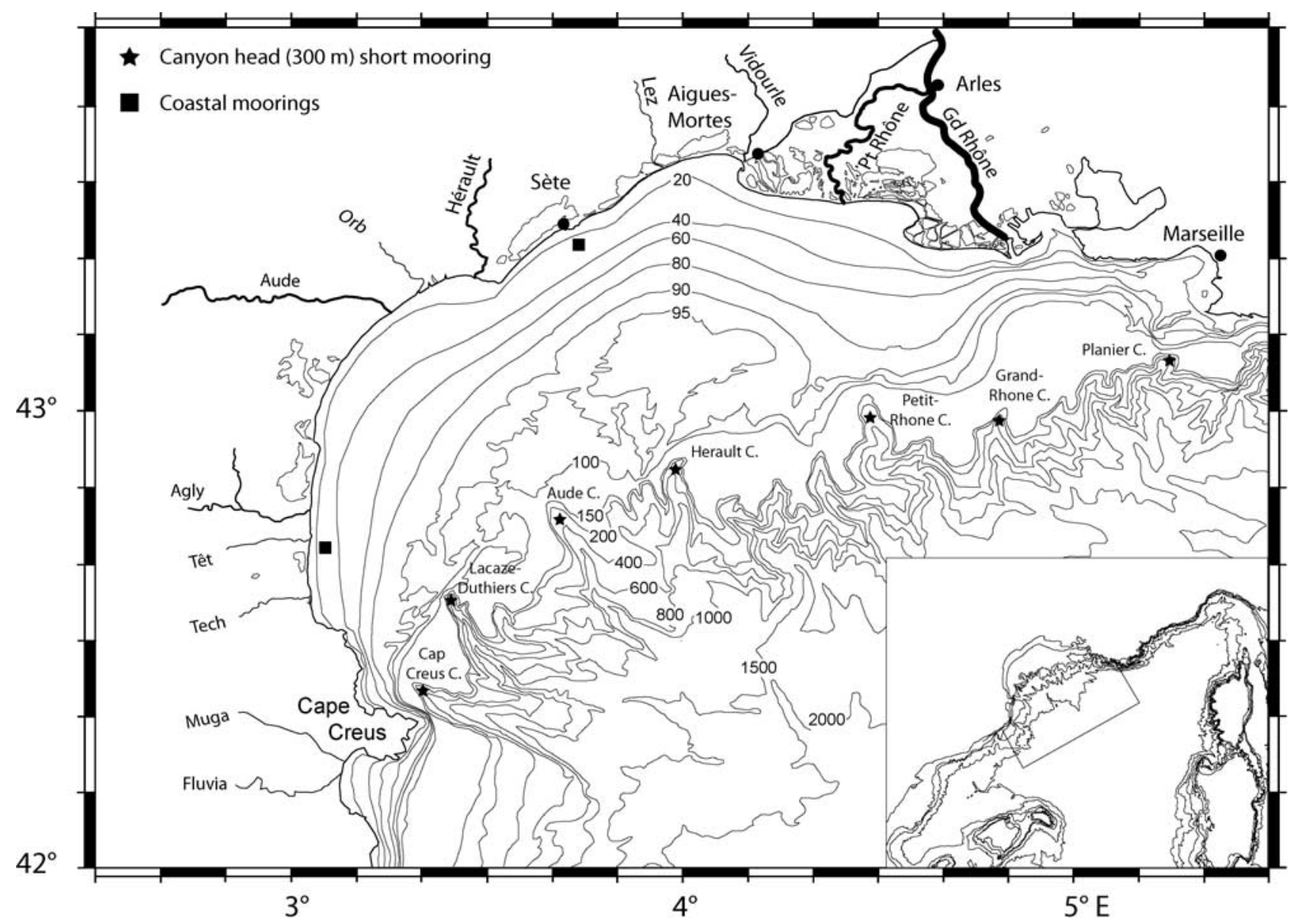

Figure 1. Bathymetric map of the Gulf of Lion with the position of the various moorings and instruments in the canyon heads (stars) and the wave gauges (squares) on the inner shelf. The insert delineates the modeling domain in the northwestern Mediterranean.

Béthoux et al. [2002] and Canals et al. [2006] inferred that during the abnormally cold winters of 1999 and 2005, respectively, intense dense shelf water cascading contributed to the renewal of the bottom waters of the deep western Mediterranean Basin. These events, which lasted one month, were traced at $1000 \mathrm{~m}$ depth on the continental slope and had downslope velocities of up to $80 \mathrm{~cm} \mathrm{~s}^{-1}$.

[17] When dense waters escape the shelf and spread around the shelf break depth, they contribute to the socalled Western Mediterranean Intermediate Water with typical properties $\mathrm{T}=12.6-13.0^{\circ} \mathrm{C}, \mathrm{S}=38.10-38.30$, density $=28.8-29.0 \mathrm{~kg} \mathrm{~m}^{-3}$ [Lapouyade and Durrieu de Madron, 2001]. In the case of dense shelf water cascading to deeper levels, they eventually mix with the warmer and saltier Levantine Intermediate Water $\left(\mathrm{T}=13.3-13.5^{\circ} \mathrm{C}, \mathrm{S}=\right.$ $38.50-38.58$, density $=29.05-29.08 \mathrm{~kg} \mathrm{~m}^{-3}$ ) that extends between 200 and $1000 \mathrm{~m}$ depth [Conan and Millot, 1995; Lapouyade and Durrieu de Madron, 2001], or with the underlying Deep Western Mediterranean Water.

\subsection{Marine Storms in the Gulf of Lion}

[18] Wave observations from the Service Maritime et de Navigation Languedoc-Roussillon (SMNLR) reveal that only four strong marine storms with significant wave height larger than $5 \mathrm{~m}$ and peak period longer than $10 \mathrm{~s}$ have occurred during the last decade (17 December 1997, 12 November 1999, 23 December 2000, and 4 December 2003) [Ferré et al., 2005; Guillén et al., 2006]. These episodes were associated with river floods as the transport of humid marine air over the coastal relief promoted high precipitations. From an annual monitoring of near-bottom particle fluxes collected with sediment traps at $600 \mathrm{~m}$ depth in the Lacaze-Duthiers Canyon, Monaco et al. [1990] hypothesized that marine storms affect the export of shelf particulate matter down the slope. Nevertheless, continuous observations since 1993 of near-bottom particle fluxes at $1000 \mathrm{~m}$ depth in the Lacaze-Duthiers and Planier Canyons have not shown a correlation of shelf-slope exchanges with marine storms [Heussner et al., 2006]. Hence the question on the effective impact of marine storms on shelf-slope exchanges is still open, in particular the physical processes responsible for the shelf-slope connections remain unclear.

\section{Material and Methods}

\subsection{Hydrodynamic Model}

\subsubsection{General Description}

[19] The SYMPHONIE model is a three-dimensional primitive equation hydrostatic model that has been described by Estournel et al. [1997]. As far as the Gulf of 
a) Wind $(\mathrm{m} / \mathrm{s})$

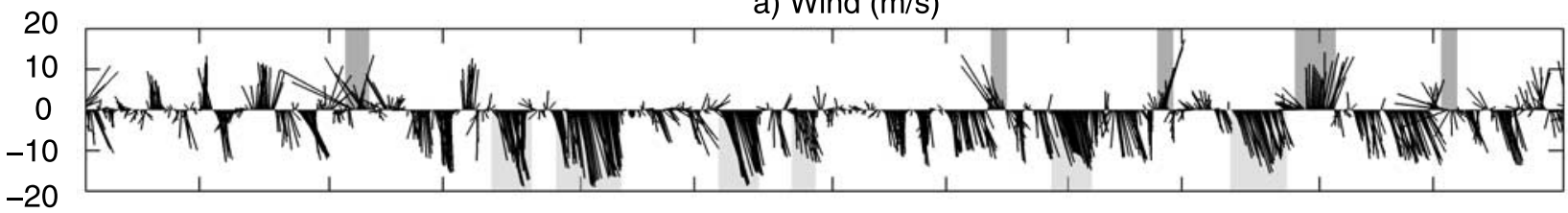

b) Significant wave height $(\mathrm{m})$

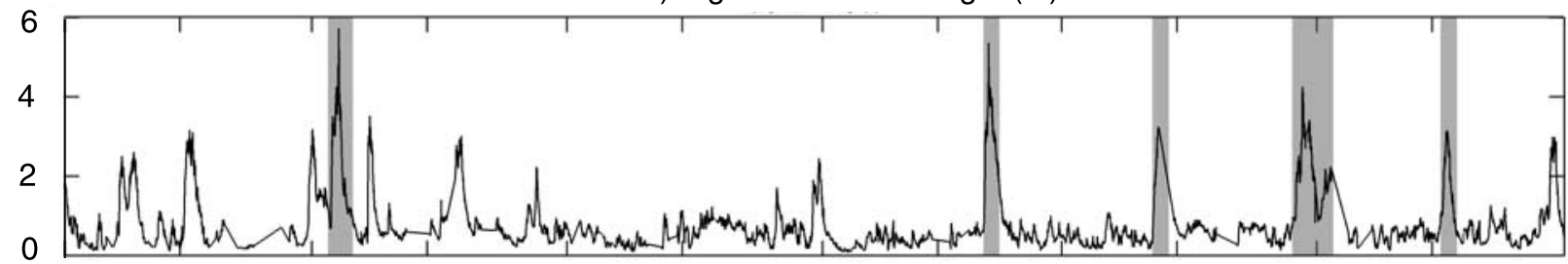

c) Sea level $(m)$

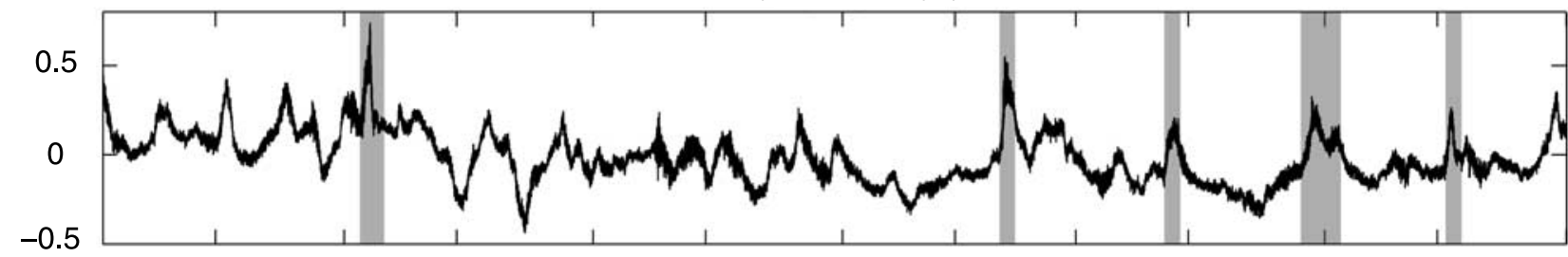

d) Rhone discharge $\left(\mathrm{m}^{3} / \mathrm{s}\right)$

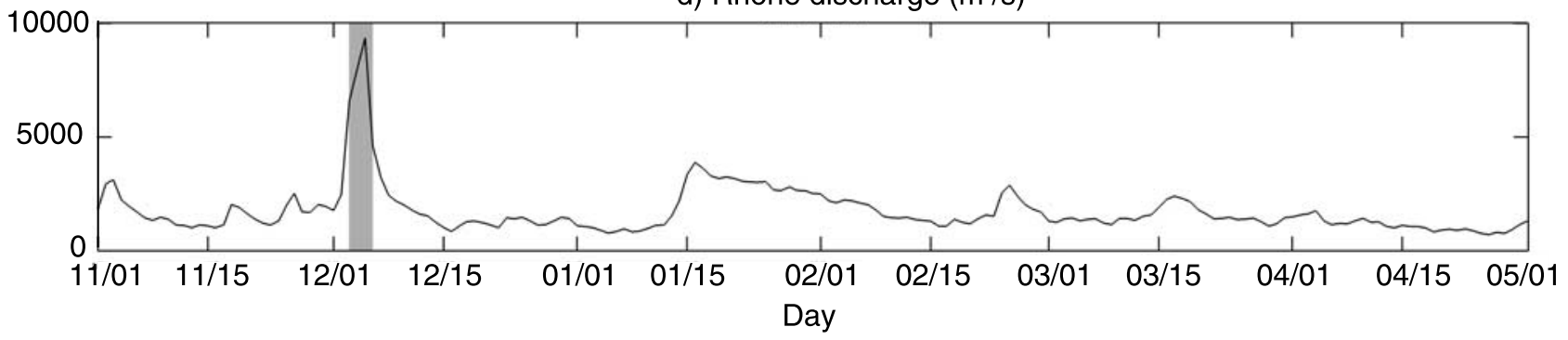

Figure 2. Time variation of (a) wind $\left(\mathrm{m} \mathrm{s}^{-1}\right)$ simulated by the ALADIN meteorological model on the inner shelf, off the Têt River mouth; (b) significant wave height (m) measured off Sète; (c) sea level (m) measured off Sète; and (d) Rhone water discharge $\left(\mathrm{m}^{3} \mathrm{~s}^{-1}\right)$ from November 2003 to May 2004. The light and dark shaded areas correspond to northerly wind and marine storm events, respectively.

Lion is concerned, this model was previously used to study the Rhone River plume [Estournel et al., 2001; Reffray et al., 2004], the intrusion of the Northern Current into the shelf [Auclair et al., 2001], the wind-induced circulation [Estournel et al., 2003; Petrenko et al., 2005; Gatti et al., 2006] and the formation of dense water on the shelf and its cascading over the slope [Dufau-Julliand et al., 2004].

[20] The current components, free surface elevation, temperature and salinity are computed on a $\mathrm{C}$ staggered grid [Arakawa and Suarez, 1983]. A generalized topographyfollowing coordinate system is used with the sigma coordinate transformation suggested by Johns and Oguz [1987]:

$$
z=(\sigma-1) h+\sigma \eta
$$

but in a generalized form (hereafter generalized sigma coordinate) described below.

[21] In the generalized sigma coordinate the vertical grid increment, $\Delta \sigma$, is a fully $3-\mathrm{D}$ variable depending on the 3 indexes of the numerical grid, $i, j, k$, when in a standard (topography-following) sigma coordinate system it depends only on the vertical grid index, $k$ [see, e.g., Mellor, 2003]. In the standard case the vertical resolution, $\Delta z$, at a given grid point $i, j, k$, is:

$$
\Delta z_{i, j, k}=(h+\eta)_{i, j} \Delta \sigma_{k}
$$

where $h$ is the motionless water column thickness and $\eta$ is the sea level anomaly, when in a generalized sigma coordinate system it is:

$$
\Delta z_{i, j, k}=(h+\eta)_{i, j} \Delta \sigma_{i, j, k}
$$

[22] It is possible, with a standard sigma system, to have an inhomogeneous distribution of the vertical levels. Indeed the vertical grid can be stretched to improve for instance the resolution near the bottom or near the surface [Johns et al., 1983]. Nevertheless formula (2) is more restrictive than formula (3) and can present some inconveniences like for instance a strong distortion of the vertical resolution between very shallow and very deep areas. Actually, considering a given vertical level $\mathrm{k}$, an appropriate vertical resolution in 


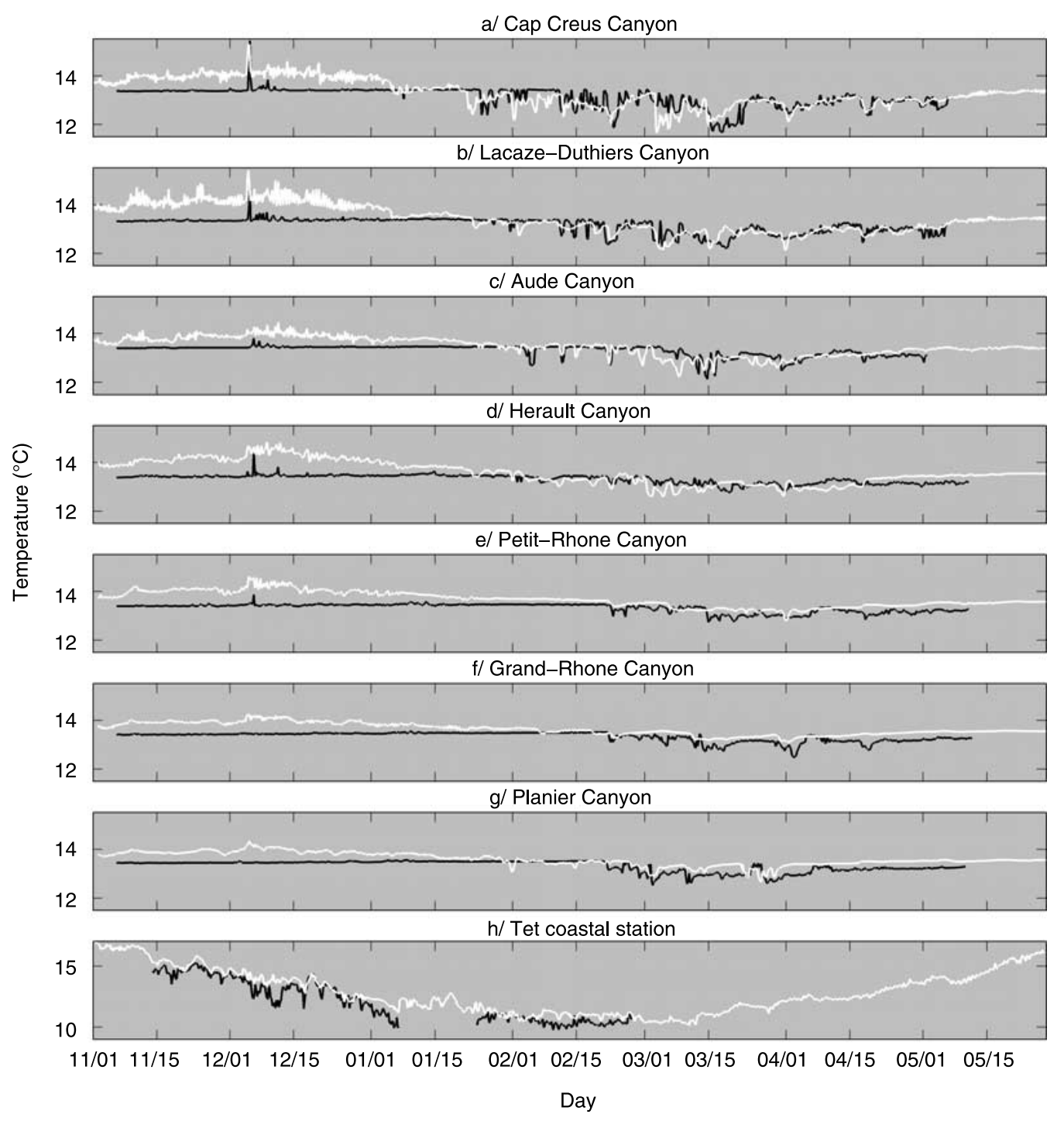

Figure 3. Comparison of observed (black) and simulated (white) (a-g) near-bottom temperature $\left({ }^{\circ} \mathrm{C}\right)$ in the canyon heads $(\sim 300 \mathrm{~m})$ (from west to east) and (h) surface temperature $\left({ }^{\circ} \mathrm{C}\right)$ at the Têt coastal station from November 2003 to May 2004.

shallow areas can possibly lead to a lack of resolution in deep areas (preventing a correct modeling of surface or bottom turbulent layers) or conversely an appropriate vertical resolution in deep areas can lead to an excessive leanness of the vertical layers, conflicting with the classical numerical stability criterions. Obviously formula (3) enables a better control of the vertical resolution since it can possibly be decided to keep $\Delta z$ constant, or nearly constant, in the upper and/or lower parts of the grid [see also Ezer and Mellor, 2004; Pietrzak et al., 2002; Mellor et al., 2002].

[23] In the present study we use a standard sigma grid in shallow areas: practically, when the bottom depth is lower than $h_{0}=150 \mathrm{~m}$, the depth of grid node is related to the vertical level number $k$ according to:

$$
\sigma_{k}=\frac{k-1}{N-1}
$$

where $k$ is increasing upward and $N$ is the total vertical level number. When $h$ exceeds $h_{0}$ we prevent the loss of resolution in the surface and bottom layers by mixing the local standard sigma coordinate with the vertical level distribution obtained when $h$ is equal to $h_{0}$. In the upper part of the grid ( $k \geq K, K$ being a vertical number, separating the upper and lower parts) the level depth is then given by:

$$
z_{i, j, k}=\left(\sigma_{k}-1\right)\left(\alpha_{k} h_{0}+\left(1-\alpha_{k}\right) h_{i, j}\right)+\sigma_{k} \eta
$$

with $\alpha_{k}=\left(\sigma_{k}-\sigma_{K}\right) /\left(\sigma_{N}-\sigma_{K}\right)$ a weighting factor enabling a smooth transition in the vertical direction (the vertical resolution tends to be close to the constant value $\Delta z \approx \Delta \sigma_{N}$ $h_{0}$ when $\mathrm{k}$ approaches the surface level number, $\mathrm{N}$, and conversely the vertical resolution is close to the standard sigma increment $\Delta z_{i, j, k} \approx \Delta \sigma_{k}(h+\eta)_{i, j}$ when $\mathrm{k}$ is close to $\mathrm{K}$ ). 


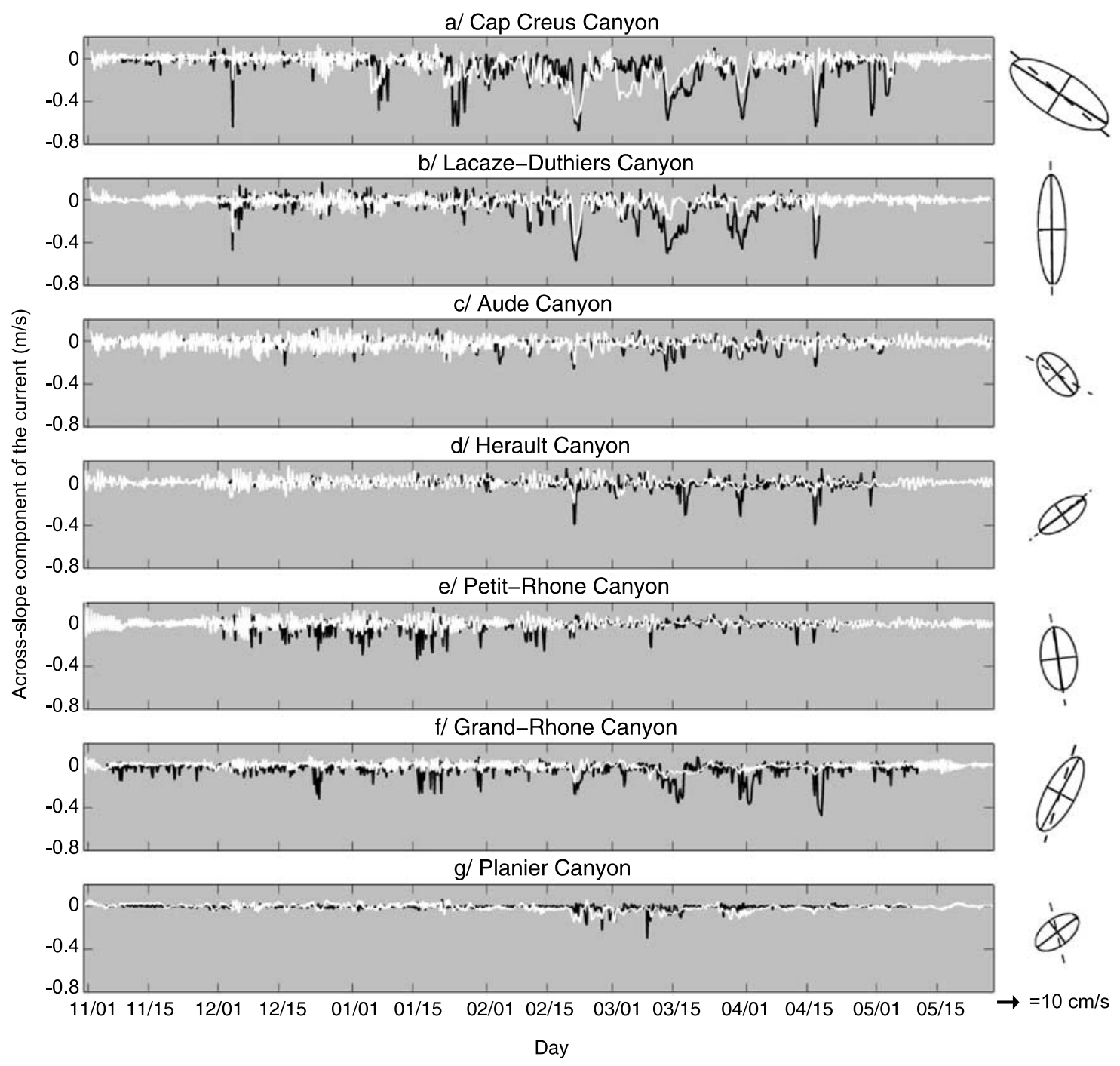

Figure 4. (a-g) Comparison of observed (black) and simulated (white) near-bottom across-slope (along canyon axis) component of the current $\left(\mathrm{m} \mathrm{s}^{-1}\right)$ in the canyon heads $(\sim 300 \mathrm{~m})$ (from west to east) from November 2003 to May 2004. The upslope component is positive. Current ellipses computed from observations are represented for each canyon. The orientation of major axis of the ellipses is close to that of the canyon axis (dashed line), except in the Planier Canyon.

[24] Conversely in the lower part of the grid $(k \leq K)$ the depth is given by:

$$
z_{i, j, k}=\sigma_{k}\left(\alpha_{k} h_{0}+\left(1-\alpha_{k}\right) h_{i, j}\right)-h_{i, j}+\sigma_{k} \eta
$$

where $\alpha_{k}=\left(\sigma_{k}-\sigma_{K}\right) /\left(\sigma_{1}-\sigma_{K}\right)$ ensures that the vertical resolution becomes close to the constant value $\Delta z \approx \Delta \sigma_{1} h_{0}$ when $\mathrm{k}$ approaches the bottom level number, 1, and conversely that the vertical resolution is close to the standard sigma increment $\Delta z_{i, j, k} \approx \Delta \sigma_{k}(h+\eta)_{i, j}$ when $\mathrm{k}$ is close to $\mathrm{K}$. In our study, the value of the vertical number $\mathrm{K}$, separating the upper and lower parts of the grid, was arbitrarily set to $0.2 \times N$.

[25] Despite some well known shortcomings of the sigma coordinate system, like the pressure truncation error [Auclair et al., 2000], dense water cascading should be better simulated with a sigma grid than with a Cartesian system, the latter locally underestimating the slope effect and thus slowing down the dense water plume motion. Compared to the standard sigma system, the generalized sigma system used here is a step toward the unstructured grid, offering various advantages described by Pietrzak et al. [2002]. Here it permits a good resolution within the bottom layer and thus a better representation of the dense water plume.

[26] The turbulence closure scheme is based on a prognostic equation for the turbulent kinetic energy and on a diagnostic equation for the mixing and dissipation length scales [Bougeault and Lacarrère, 1989]. A leapfrog scheme is used for the time stepping. A time-splitting technique [Blumberg and Mellor, 1987] allows the vertical shear of the current and the depth-averaged horizontal components to be computed separately with appropriate time steps.

[27] The use of a hydrostatic model is somehow questionable here since strong variations of current are likely to be found through the head of the dense water plumes. 


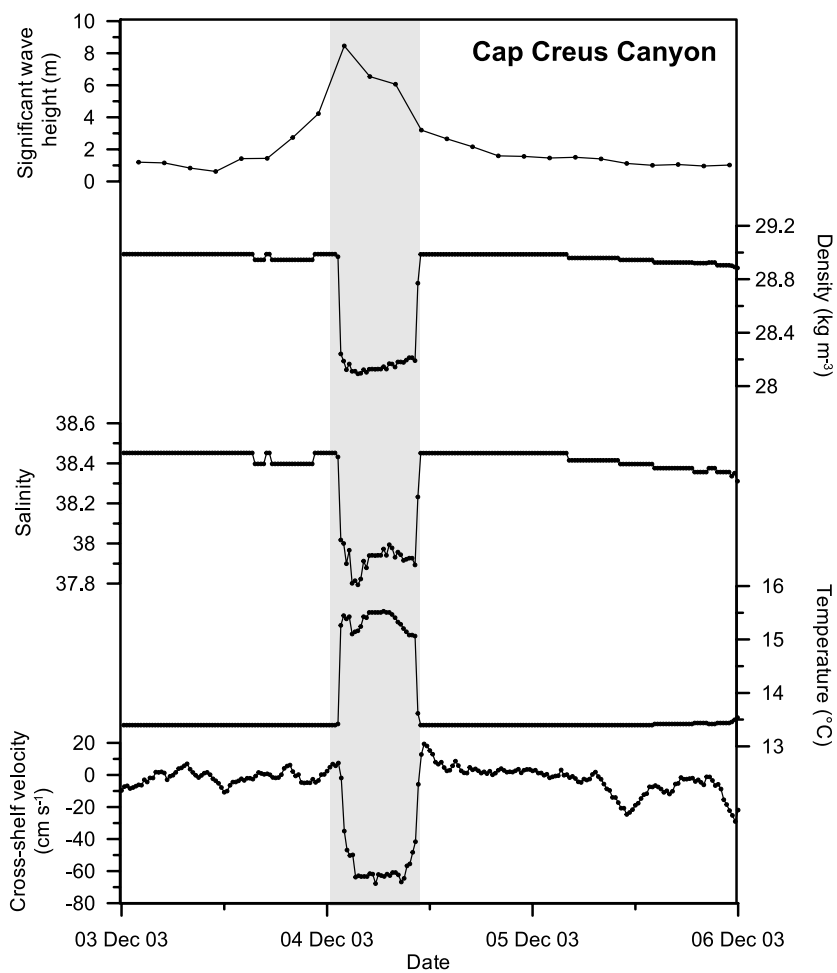

Figure 5. Blowup of the storm event that occurred on 4 December 2003 in the Cap Creus Canyon. Raw time series of: significant wave height $(\mathrm{m})$ recorded at the Têt coastal station and temperature $\left({ }^{\circ} \mathrm{C}\right)$, salinity, density $\left(\mathrm{kg} \mathrm{m}^{-3}\right)$ and across-isobath component of the current $\left(\mathrm{cm} \mathrm{s}^{-1}\right)$ recorded at $300 \mathrm{~m}$ depth. Currents during the stormy event (shading) were directed down-canyon.

Heggelund et al. [2004] described hydrostatic and nonhydrostatic simulations of dense water plumes flowing down a continental slope, using a model rather similar to the one used here. Their conclusions were that the shape of the plume head is quite sensitive to the hydrostatic or nonhydrostatic issue, the nonhydrostatic case being closer to what is generally expected from theory. On the other hand, the thickness of the plume behind the head and the time required for the dense water to reach the depth of buoyancy equilibrium seem nearly the same in both cases. So, as far as we are more concerned with global issues than plume dynamics itself, the use of a hydrostatic model seems acceptable, especially if we consider that the computation of the nonhydrostatic pressure elliptic equation is quite expensive. For the same cost, the hydrostatic model will have a better resolution and/or a larger domain and will finally better represent the background circulation, playing a significant role on the dense water fate [Shapiro and Hill, 1997; Dufau-Julliand et al., 2004].

\subsubsection{Initialization and Boundary Conditions}

[28] A downscaling method, described by Ulses et al. [2005] and Guizien et al. [2006], using three levels of grid nesting was performed in order to take into account the influence of the open sea circulation and to give a more precise description of the southwestern part of the Gulf of
Lion, where dense water cascading is intense [Béthoux et al., 2002; Dufau-Julliand et al., 2004; Canals et al., 2006].

[29] As a first step, a simulation of the northwestern Mediterranean Sea was performed with a regional model (40 sigma-step vertical levels and $3 \mathrm{~km}$ horizontal resolution), which extends from the Gulf of Valencia to the Ligurian Sea $\left(-0.34-10.95^{\circ} \mathrm{E} \times 38.26-45.61^{\circ} \mathrm{N}\right)$. The model was initialized and forced by OPA model daily outputs (MFS project) using the variational inverse method described by Auclair et al. [2006]. Afterward, a simulation of the Gulf of Lion circulation was performed using the 3-h outputs from the previous simulation for initialization and lateral open boundary forcings. The domain of the Gulf of Lion model (25 vertical levels and $1.5 \mathrm{~km}$ horizontal resolution) is shown in Figure 1. Finally, the outputs obtained during the second run were used for initialization and lateral open boundary forcings of the high-resolution model of the southwestern part of the Gulf of Lion (20 vertical levels and $500 \mathrm{~m}$ horizontal resolution). The conditions applied at the open lateral boundaries have been described by Marsaleix et al. [2006].

[30] For the atmospheric forcings, the 6-h outputs (radiative solar and long-wave fluxes, surface pressure, air temperature, relative humidity and wind velocity) of the high-resolution meteorological model ALADIN from Météo-France were used. The wind stress and the heat fluxes were computed with bulk formulae [Geernaert, 1990] using the air parameters and the sea surface temperature computed by the ocean model.

[31] The fresh water inputs from the main rivers of the Gulf of Lion (Grand-Rhone, Petit-Rhone, Vidourle, Lez, Herault, Orb, Aude, Agly, Têt, Tech) and of the Gulf of Rosas (Fluvia, Muga) were taken into account. Daily discharges supplied by the Compagnie Nationale du Rhône, the Banque Hydro and the Agència Catalana de l'Aigua were specified at the twelve river mouths. The temperature in all rivers was set following measurements in the Rhone River [Poirel et al., 2001], with a maximum value of $22^{\circ} \mathrm{C}$ in October (beginning of the simulation) and a minimum value of $7^{\circ} \mathrm{C}$ in January and February.

\subsection{Hydrological and Current Data}

[32] Temperature, salinity, density and current velocity and direction were measured using instruments moored at $\sim 300 \mathrm{~m}$ depth in the head of seven submarine canyons distributed along the continental slope of the Gulf of Lion (Figure 1). All the moorings had the same design and included a near-bottom Aanderaa RCM9/11 Doppler current meter positioned at 5 meters above the bottom (mab) and an Aanderaa RCM7/8 rotor current meter set at $25 \mathrm{mab}$. The deployment spanned from 5 November 2003 to 5 May 2004 and all instruments were set to sample at 20-min intervals. Temperature and conductivity data were compared and calibrated versus CTD data. Salinity and density were computed using the equation of state of seawater EOS80 [Fofonoff and Millard, 1983].

[33] Surface temperature of the inner shelf water was measured between late November 2003 and late February 2004 with a YSI 6600 CTD probe mounted on a buoy moored 1.2 miles off the Têt River mouth (depth $=28 \mathrm{~m}$, Figure 1). 


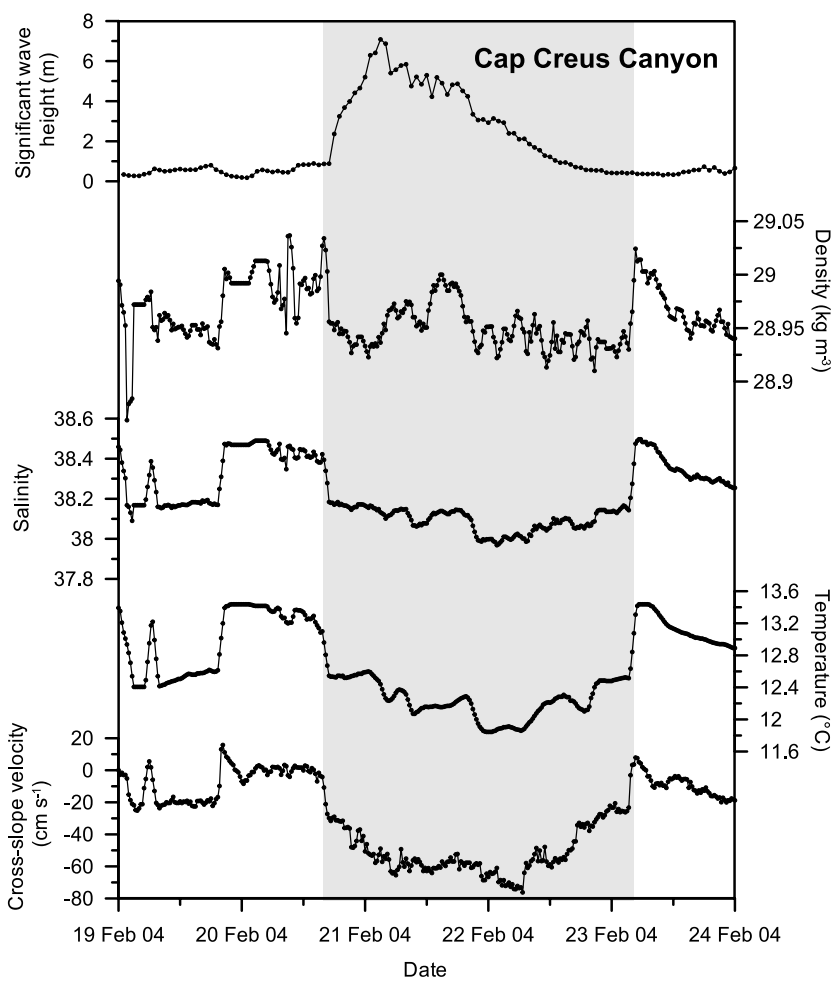

Figure 6. Blowup of the storm event that occurred on 21 February 2004 in the Cap Creus Canyon. Raw time series of: significant wave height $(\mathrm{m})$ recorded at the Têt coastal station and temperature $\left({ }^{\circ} \mathrm{C}\right)$, salinity, density $\left(\mathrm{kg} \mathrm{m}^{-3}\right)$ and across-isobath component of the current $\left(\mathrm{cm} \mathrm{s}^{-1}\right)$ recorded at $300 \mathrm{~m}$ depth. Currents during the stormy event (shading) were directed down-canyon.

\subsection{Sea State and Sea Level}

[34] Wave data were obtained from an ADCP RDI sentinel $600 \mathrm{kHz}$ model equipped with a wave pressure sensor deployed near the buoy off the Têt River mouth and from a nondirectional wave buoy located on the inner shelf off Sète (depth $=32 \mathrm{~m}$, Figure 1), managed by the SMNLR. Sea surface level was measured off Sète by float-based tide gauges every 2 min (data from the SMNLR). The tidal signal was removed using harmonic analyses for high frequencies, and using the predictions of the FES2002 model [Letellier, 2004] for low frequencies.

\section{Results and Discussion}

\subsection{Field Observations}

\subsubsection{Meteorological, River Discharge, and Wave Climate}

[35] Time series of wind, significant wave height, sea level and Rhone River discharge for the study period are presented on Figure 2. The observation period was characterized by five marine onshore storms (early December, late February, mid-March, early and mid-April). The early December and late February events had wind speeds higher than $16 \mathrm{~m} \mathrm{~s}^{-1}$ and corresponded to sea level increases exceeding $50 \mathrm{~cm}$ near the coast. During the December storm, floods following extremely high precipitations affected all rivers of the Gulf of Lion with a markedly high
Rhone River discharge that reached an exceptional daily value of $9346 \mathrm{~m}^{3} \mathrm{~s}^{-1}$ (monthly mean discharge for the period 1974-2006: $1965 \mathrm{~m}^{3} \mathrm{~s}^{-1}$ ). Following this fall storm, four northerly continental wind episodes (DecemberJanuary) were associated with strong heat losses and low sea levels. A moderate increase of the Rhone River discharge $\left(\sim 4000 \mathrm{~m}^{3} \mathrm{~s}^{-1}\right)$ was recorded in mid-January. Later on, from February to the end of the observation period, northerly winds alternated with easterly to southeasterly winds.

[36] Thus three periods were identified: (1) a fall period with a stratified water column marked by a strong marine storm accompanied by an exceptional flood of all rivers of the Gulf; (2) a first typical winter period characterized by strong, cold northerly winds; and (3) a second winter period marked by several marine storms.

\subsubsection{Hydrological and Current Time Series}

[37] The temperature and current velocity observed in the canyon heads during the study period were described by Palanques et al. [2006]. We briefly present these observations before comparing them with model outputs. Figures 3 and 4 present time series of the near-bottom temperature and across-slope component of the current recorded in the canyon heads ( $\sim 300 \mathrm{~m}$ deep) and the surface temperature measured at the Têt coastal station. Their variability and amplitude were clearly higher in the western canyons than

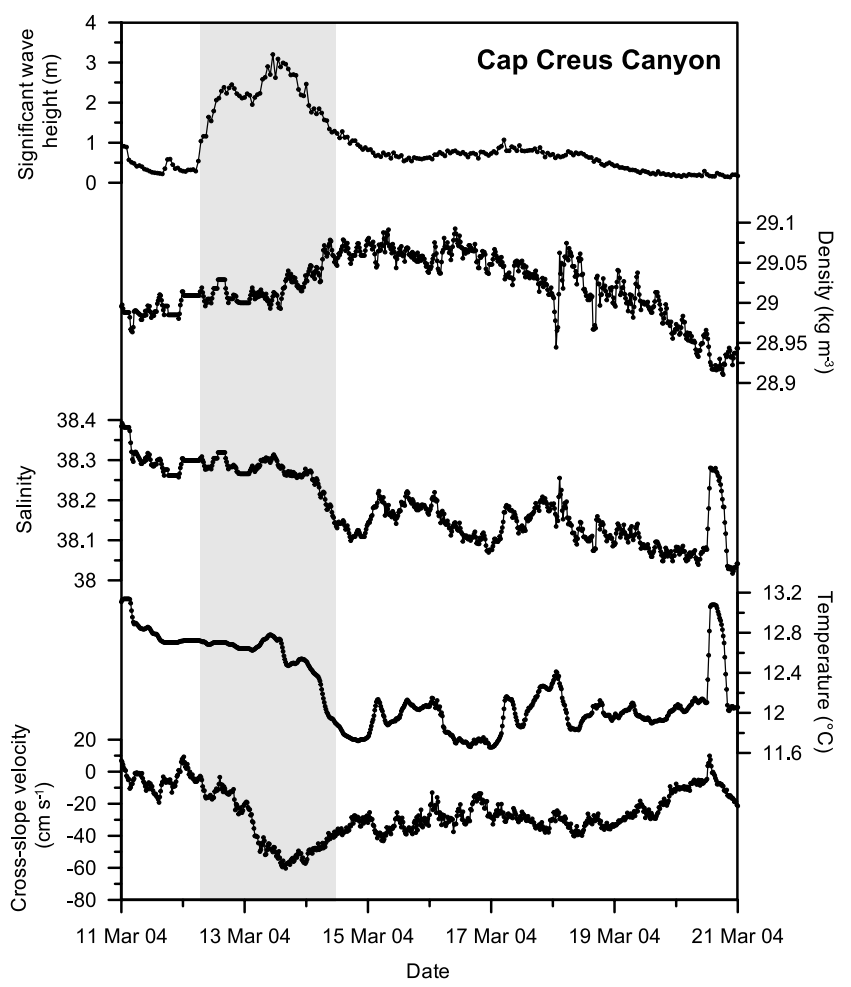

Figure 7. Blowup of the storm event that occurred on $12-$ 14 March 2004 and the subsequent cascading in the Cap Creus Canyon. Raw time series of significant wave height (m) recorded at the Têt coastal station and temperature $\left({ }^{\circ} \mathrm{C}\right)$, salinity, density $\left(\mathrm{kg} \mathrm{m}^{-3}\right)$ and across-isobath component of the current $\left(\mathrm{cm} \mathrm{s}^{-1}\right)$ recorded at $300 \mathrm{~m}$ depth. Currents during the stormy event (shading) were directed downcanyon. 

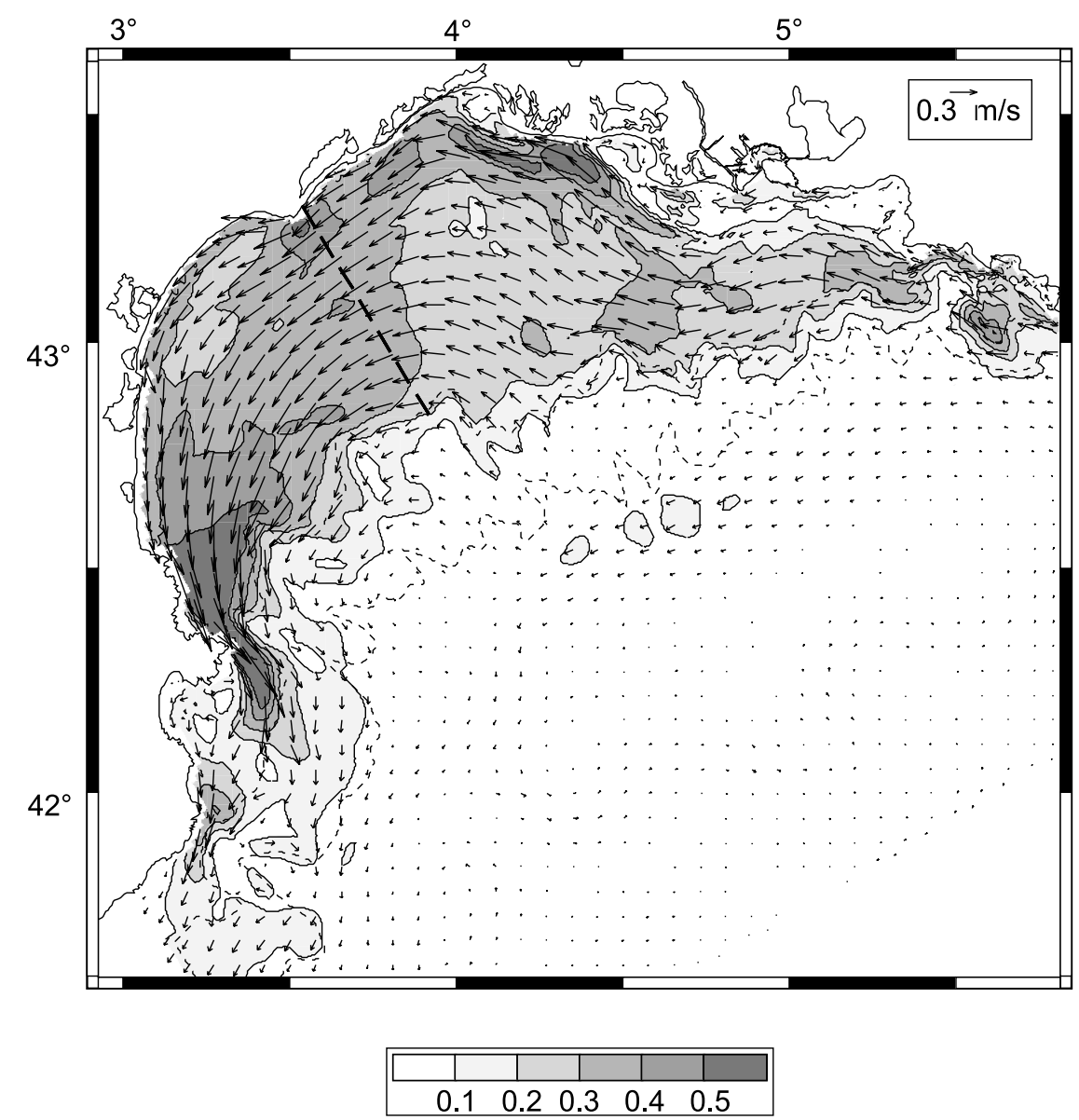

Figure 8. Simulated depth-averaged current field $\left(\mathrm{m} \mathrm{s}^{-1}\right)$ on 4 December 2003 at 0000 LT, showing the acceleration of the current in the southwest of the Gulf. Isobaths 150 and $1000 \mathrm{~m}$ are superimposed as fine dashed lines. The thick dashed line indicates the section across which a $1.5 \mathrm{~Sv}$ flux was calculated.

in their eastern counterparts. Temperature in the canyons was practically constant during a long period from early November to early January, at the exception of a short and sharp increase in early December. Then it showed intermittent drops until late March with large cooling events (maximum $2^{\circ} \mathrm{C}$ ). Near-bottom currents were preferentially oriented along the axis of the canyon, except in the Planier Canyon.

[38] The stable temperature and the relatively weak currents measured at $300 \mathrm{~m}$ deep in the canyon heads during the fall period were characteristic of the conditions that prevailed on the upper slope [Albérola and Millot, 2003] and indicate that the canyon heads were not influenced by the coastal water characterized by warmer temperatures. Furthermore, the bottom currents remained relatively weak during most of this period. An exception was observed for the early December event, where a sharp increase in temperature, a drop in salinity and hence an appreciable drop in density were recorded in the western canyons (Figure 5). The observed water mass was thus clearly identified as shelf water. Moreover, the abrupt thermohaline anomaly associated with advection of coastal water was marked by a strong downslope flow (velocity = $70 \mathrm{~cm} \mathrm{~s}^{-1}$ ). This event corresponded to the short, vigorous marine storm. So, during the stratified fall conditions, marine storms appear to promote shelf-slope exchanges of seawater.

[39] On the inner shelf, off the Têt River mouth, temperature time series indicate that a strong cooling took place during the second half of December (Figure 3h). From 17 December 2003 to 4 January 2004, a temperature decrease of about $3-4^{\circ} \mathrm{C}$ was observed. This was related to two northerly wind episodes associated with strong surface heat losses $\left(>350 \mathrm{~W} \mathrm{~m}^{-2}\right)$.

[40] During winter conditions (January-March), several consecutive temperature drops were recorded in the submarine canyon heads (Figures $3 \mathrm{a}-3 \mathrm{~g}$ ). These cooling periods occurred earlier and were stronger in the southwestern part of the Gulf. They were associated with lower salinity and stronger currents (Figures 6 and 7), reflecting the intermittent downslope advection of shelf water. Our observations in the canyons' heads show that during winter several pulses of shelf water flowed over the shelf edge, and provide new insight into the cascading process that was previously perceived as a continuous phenomenon occurring after persistent strong northerly winds [Dufau-Julliand et al., 2004].

[41] Temperature anomalies and, particularly, current increases are strong during easterly to southeasterly wind events. This suggests that marine storm (in stratified or mixed conditions) is a major forcing event for shelf-slope 

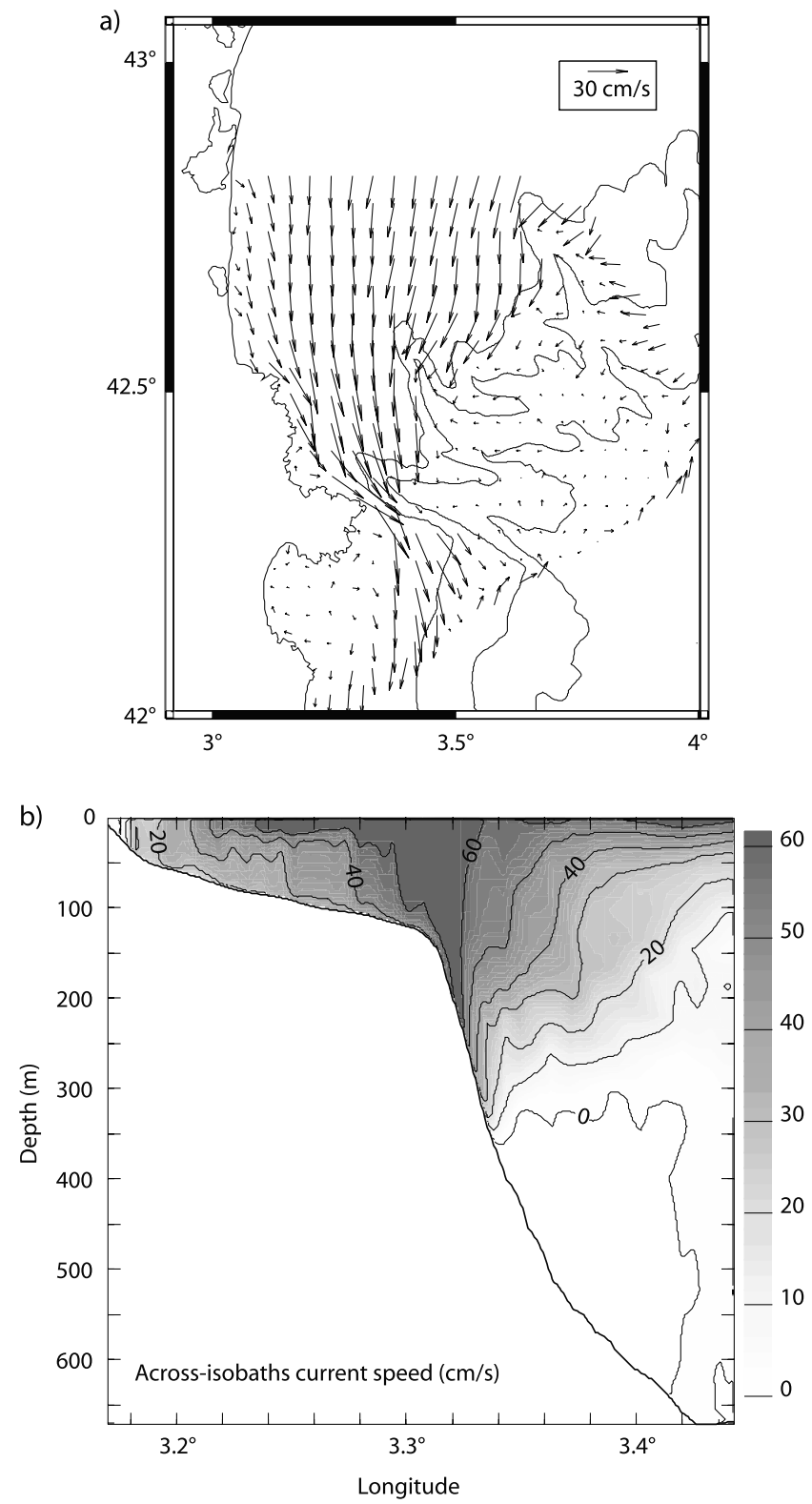

Figure 9. Simulated (a) near-bottom current and (b) vertical section of the across-isobaths component of the current $\left(\mathrm{cm} \mathrm{s}^{-1}\right)$ in the Cap Creus Canyon, for 4 December 2003 at 0600 LT. See Figure 10a for section location. The offshore direction corresponds to positive values. Isobaths 150,500 and $1000 \mathrm{~m}$ are superimposed as lines on Figure 9a.

exchanges. However, the density of shelf water probably modulates the impact of storms on the intensity of exchanges. During fall, buoyancy effects associated to the strong stratification of the water column might limit the export of shelf water down the slope. Conversely, the destratification and the increase of shelf water density during wintertime might strengthen via cascading the export of shelf water down the slope.

[42] From those observations, two fundamental questions arise: (1) What is the shelf and slope circulation during marine storms, and what is the effect of the seasonal changes of the water column stratification? (2) How are dense water formation, propagation and cascading during a winter marked by significant fresh water inputs and unusually frequent marine storms?

[43] Observations alone do not provide answers to the questions listed above concerning the mechanisms controlling shelf-slope exchanges. Local observations at mooring sites are not informative on the shelf-wide responses to wind in terms of mixing and dense water formation on the shelf. Furthermore, the inner shelf deployment located in front of the Têt River mouth may have been strongly influenced by local rivers and may not correctly describe the mixing induced by the continental winds. The model then helps us to understand the time-space evolution of shelf water that conditions the mass exchanges with the slope and the impact of marine storms and dense water cascading on shelf-slope exchanges.

\subsection{Validation of Modeling Results}

\subsubsection{Shelf}

[44] On the shelf, in front of the Têt River mouth, the model reproduces reasonably well the general trend of the observed surface temperature: first its decrease from December to January and then its relative stabilization in February (Figure $3 \mathrm{~h}$ ). The time-averaged difference between modeled and observed temperature $\overline{\left(\left|f_{\text {observation }}-f_{\text {model }}\right|\right.}=\frac{1}{N} \sum_{n=1}^{N}\left|f_{\text {observation }}^{n}-f_{\text {model }}^{n}\right|, N$ being the number of points, $f$ the considered field, here the temperature) is $0.6^{\circ} \mathrm{C}$ with a standard deviation $(\sigma=$ $\left.\left[\frac{1}{N} \sum_{n=1}^{N}\left(\left|f_{\text {observation }}^{n}-f_{\text {model }}^{n}\right|-\overline{\left|f_{\text {observation }}-f_{\text {model }}\right|}\right)^{2}\right]^{1 / 2}\right)$ of $0.44^{\circ} \mathrm{C}$. Some discrepancies can be detected during the December flood period during which observed salinity decreased to 24 (not shown). At the same period, low observed temperature values were probably linked to river and/or rainfall water not correctly taken into account in the model and probably corresponding to very surficial processes.

\subsubsection{Slope}

[45] In the western canyons (Cap Creus, Lacaze-Duthiers, Aude, Herault), the model reproduces the specific increases of the across-slope (along canyon axis) component of the current during marine storms, although an important underestimation during these peak events is visible (Figure 4). In the Petit-Rhone and Grand-Rhone Canyons, the model underestimates the across-slope component of the current most of the period. In the easternmost canyon (Planier), modeling and observations agree reasonably well and show strong currents from 20 February to 1 April.

[46] Concerning the temperature anomaly during fall, the model clearly retains the temperature provided by the ocean general circulation model (OGCM), which is higher than the observations (Figure 3). Comparisons (not shown) with temperature and salinity profiles recorded in fall during several years (source: Medatlas) show that the OGCM does not produce sufficiently cold and saline water within the upper $500 \mathrm{~m}$ along the slope of the Gulf of Lion. In addition, vertical gradients of salinity and temperature near the surface are higher than in the observed profiles. Therefore, as salinity and temperature are fairly well reproduced on the shelf, the equilibrium level of shelf water exported on 
a)

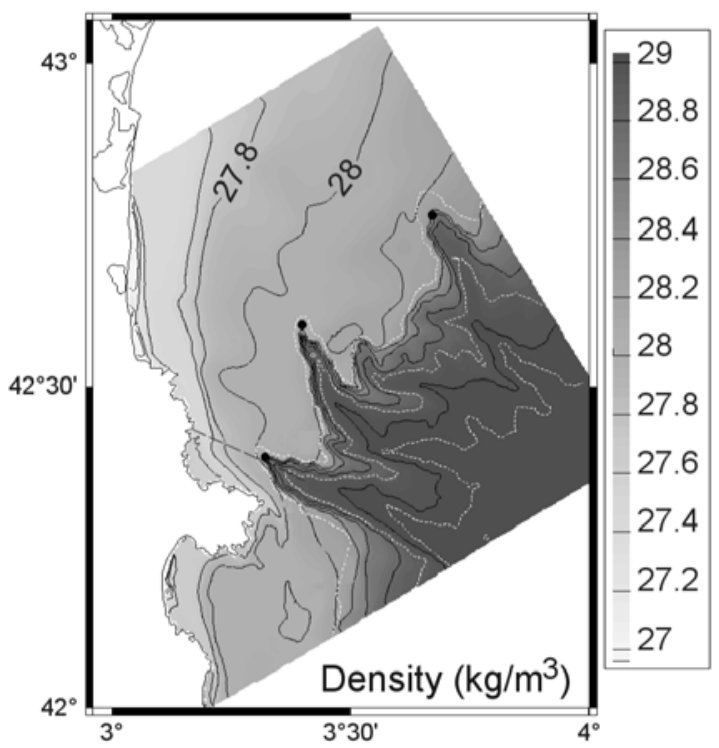

b)

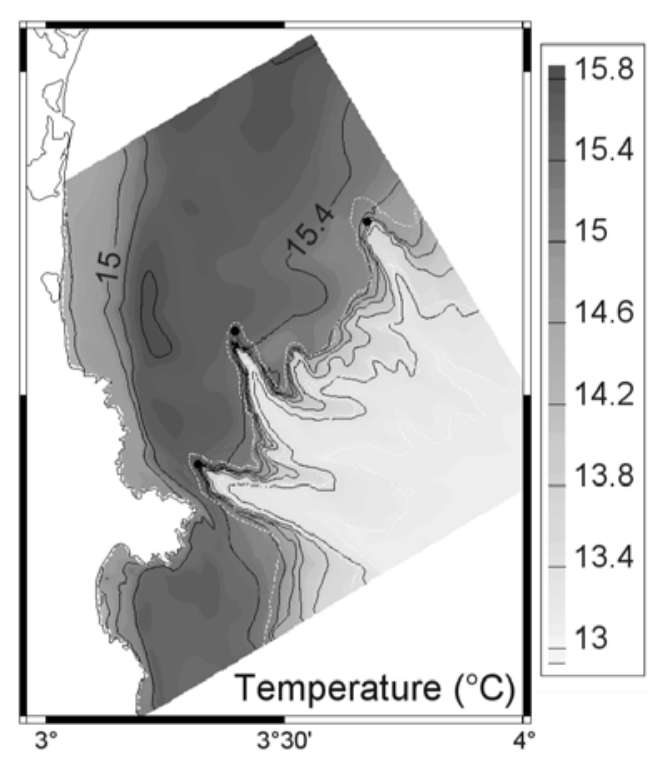

Figure 10. Simulated near-bottom (a) density $\left(\mathrm{kg} \mathrm{m}^{-3}\right)$ and (b) temperature $\left({ }^{\circ} \mathrm{C}\right)$ in the southwestern Gulf of Lion on 4 December 2003 at 0600 LT. The position of the mooring along the canyon axis is indicated with black dots. Isobaths 150,500 and $1000 \mathrm{~m}$ are superimposed as white dashed lines.

the slope is expected to be overestimated. Despite these discrepancies, the positive anomaly corresponding to the December storm is present in the model outputs. The overestimated variability can be attributed to the previously mentioned default in the vertical gradient. During wintertime, the model reproduces relatively well the intensity of temperature fluctuations.

[47] The time-averaged difference between observations and model outputs and the corresponding standard deviation over the seven studied canyon grid points are $0.36^{\circ} \mathrm{C}$ and $0.26^{\circ} \mathrm{C}$, respectively, for the temperature and $4.8 \mathrm{~cm} \mathrm{~s}^{-1}$ and $5.3 \mathrm{~cm} \mathrm{~s}^{-1}$, respectively, for the across-slope component of the current. These values present a spatial variability. For instance, in the Cap Creus Canyon characterized by a strong variability, the mean difference between model and data for the across-slope component of the current is $6.1 \mathrm{~cm} \mathrm{~s}^{-1}$ with a standard deviation of $7.4 \mathrm{~cm} \mathrm{~s}^{-1}$, and in the Planier Canyon characterized by a low signal and less variations, it is $2.5 \mathrm{~cm} \mathrm{~s}^{-1}$ with a standard deviation of $2.6 \mathrm{~cm} \mathrm{~s}^{-1}$.

[48] To sum up, the model reproduces reasonably well the major characteristics observed from the moorings on the western inner shelf and in the canyon heads. The spatial variability is correctly reproduced, which allows us to investigate in detail in the following sections the circulation and shelf water export induced by marine storms during both stratified and unstratified conditions.

\subsection{Marine Storm During Stratified Conditions}

[49] This section focuses on the early December storm, marked by strong anomalies in temperature, salinity and across-slope (along canyon axis) velocity in the western canyons (example in the Cap Creus Canyon, Figure 5). Observations evidence the rapidity of the transfer of shelf water down to the canyons, which lasted less than $12 \mathrm{~h}$.

[50] This short and intense event was characterized by the progression of an easterly-southeasterly wind traveling westward from 3 to 4 December and associated with heavy rainfall. Figure 8 presents the simulated depth-averaged current field on 4 December. It shows a cyclonic circulation over the whole shelf. The wind was parallel to the northern coast, leaving it to its right, and perpendicular to the western coast. It therefore led to a massive accumulation of seawater along the coast. Sea level off Sète (Figure 1) exceeded $70 \mathrm{~cm}$ (Figure 2c) and a similar value was observed off PortVendres in the southwestern part of the Gulf (not shown). The surface steepness produced by the wind generated a current with a strong barotropic component over the whole Gulf. In addition, fresh waters from the flooded rivers formed a cold, low-salinity band flowing cyclonically along the coast and accelerated by the wind. The along-shelf flux in the center of the Gulf (across the section indicated on Figure 8 by a dashed line) was about $1.5 \mathrm{~Sv}$. At the southwestern extremity of the Gulf, the shelf is very narrow $(\sim 2 \mathrm{~km})$ and is limited offshore by the Cap Creus Canyon. This narrowing, together with the progressive acceleration of water mass due to the transfer of wind momentum, resulted in a large acceleration of the currents toward the southwest. A depth-averaged current of $\sim 3 \mathrm{~m} \mathrm{~s}^{-1}$ would then be required on the southwestern end of the Gulf to flush all the shelf water converging in this area. However, bottom friction reduced the velocity on the shelf and the excess of shelf water that could not escape around the Cap Creus promontory was drained into the nearby canyons (Figure 9a). Since shelf water was lighter than canyon water, the downwelling was limited to $\sim 300 \mathrm{~m}$ depth in the Cap Creus Canyon (Figure 9b). The shelf water was then mainly flushed southward on the Spanish shelf and offshore near the surface.

[51] Bottom density and temperature in the southwestern region are presented in Figure 10, showing the characteristics of the exported shelf water. Light $\left(\mathrm{T}=14.6^{\circ} \mathrm{C}, \mathrm{S}=\right.$ 36.75 ) river waters were transported along the coast toward 

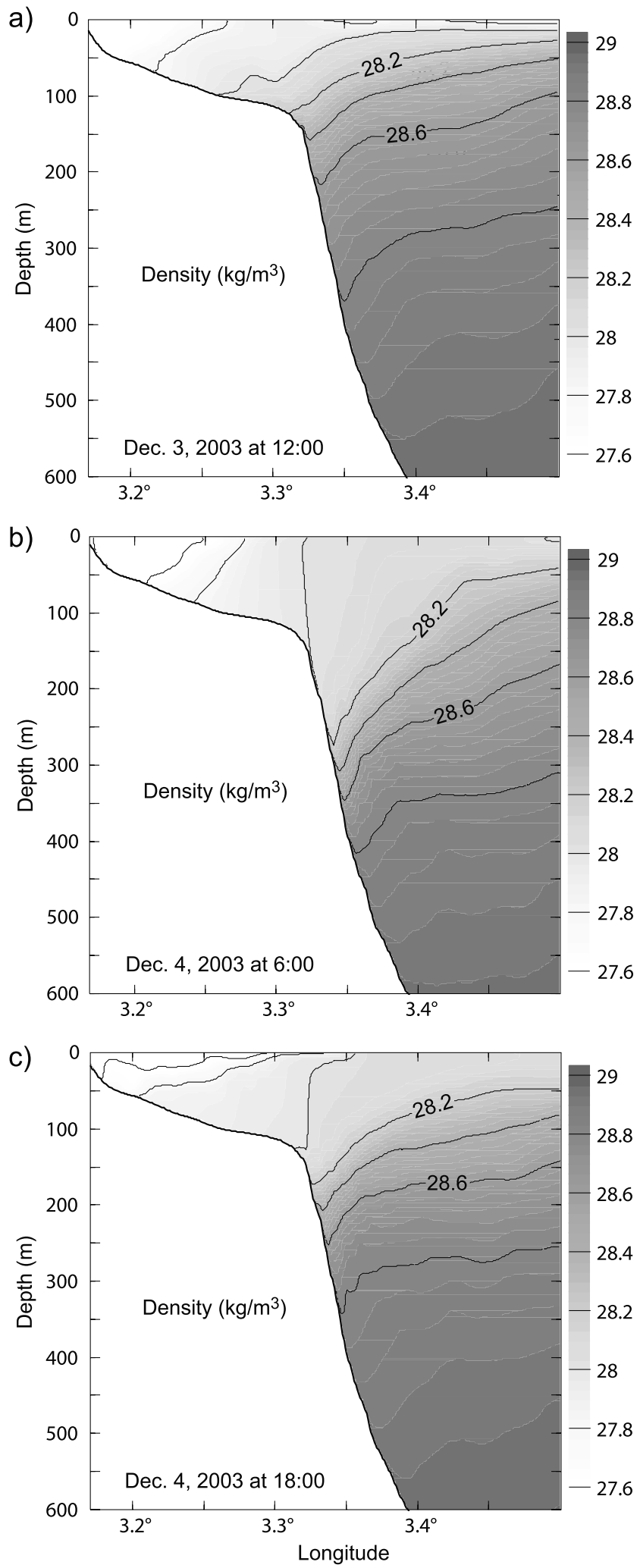

Figure 11. Cross sections of the simulated density $\left(\mathrm{kg} \mathrm{m}^{-3}\right)$ in the Cap Creus Canyon (a) before (3 December at 1200 LT), (b) during (4 December at 0600 LT) and (c) after (4 December at $1800 \mathrm{LT}$ ) the storm. See Figure 10a for section location. the Spanish shelf, whereas a part of the denser $\left(\mathrm{T}=15.5^{\circ} \mathrm{C}\right.$, $\mathrm{S}=37.75$ ) outer shelf water was advected down the canyons. Figure 11 shows the variation of the vertical density structure in the Cap Creus Canyon before, during and after the December storm. Before the storm (3 December at 0000 local time (LT), Figure 11a), the water column in the canyon was stratified as shown by the nearly horizontal isopycnals. The day of the storm (4 December at $0600 \mathrm{LT}$, Figure $11 \mathrm{~b})$, water from the outer shelf $\left(28 \mathrm{~kg} \mathrm{~m}^{-3}<\right.$ density $<28.2 \mathrm{~kg} \mathrm{~m}^{-3}$ ) was advected into the Cap Creus Canyon down to $300 \mathrm{~m}$ depth under the effect of the intense storm-induced downwelling. Immediately after the storm (4 December at 1800 LT, Figure 11c), the isopycnals relaxed back toward their initial position. These results illustrate that the model is able to reproduce the suddenness of the process and, associated with the validation presented in section 4.2, confirm its potential to provide an accurate estimation of the processes involved and of the exported mass fluxes.

[52] In addition, modeled Lagrangian drifters (not shown) were used to determine the trajectories of the light shelf water downwelled between 200 and $300 \mathrm{~m}$ depth in the Cap Creus Canyon: at the end of the storm, most of the modeled drifters rose up rapidly on to the Spanish shelf and traveled southward, while the rest rose up near the surface and remained within the canyon head. Hence the fall marine storm generated rapid shelf water export along the coast and down the head of the western canyons. However, the transfer was limited to the upper slope by the water column stratification that still existed in early December.

\subsection{Dense Water Formation and Cascading}

[53] The winter of 2004, during which the experiment was conducted, was not a cold winter. In order to better differentiate this winter from previous winters, the number of days during which northerly winds blew was calculated using meteorological observations in the southwestern part of the Gulf of Lion from December 2003 to March 2004. This number was compared with that obtained over the extremely cold winter of 1999 and with an average computed over the 1973-2001 winter periods (Table 1). Winter 1999 experienced very cold and frequent strong northerly winds. In contrast, the number of days of intense cold wind (7 d) during the winter of 2004 clearly appears to be lower than the average $(16 \mathrm{~d})$. It can also be noted from this analysis that periods of northerly wind were brief $(4 \mathrm{~d}$ maximum). Besides, the exceptional flood recorded in all

Table 1. Wind Speed and Air Temperature Recorded by Meteorological Stations in the Southwestern Part of the Gulf of Lion From December to March

\begin{tabular}{lccc}
\hline & \multicolumn{3}{c}{$\begin{array}{c}\text { Number of Days With } \\
\text { Northerly Wind From } \\
\text { December to March }\end{array}$} \\
\cline { 2 - 4 } & $\begin{array}{l}\text { Average for } \\
1973-2001\end{array}$ & $1998 / 1999$ & $2003 / 2004$ \\
\hline $\mathrm{V}>10 \mathrm{~m} \mathrm{~s}^{-1}$ & 57.3 & 68 & 28 \\
$\mathrm{~V}>10 \mathrm{~m} \mathrm{~s}^{-1}$ and $\mathrm{T}_{\text {air }}<8^{\circ} \mathrm{C}$ & 16 & 22 & 7 \\
$\begin{array}{l}\text { Maximum number of days } \\
\text { where } \mathrm{V}>10 \mathrm{~m} \mathrm{~s}^{-1}\end{array}$ & 11.5 & 29 & 4 \\
consecutively & & & \\
\hline
\end{tabular}



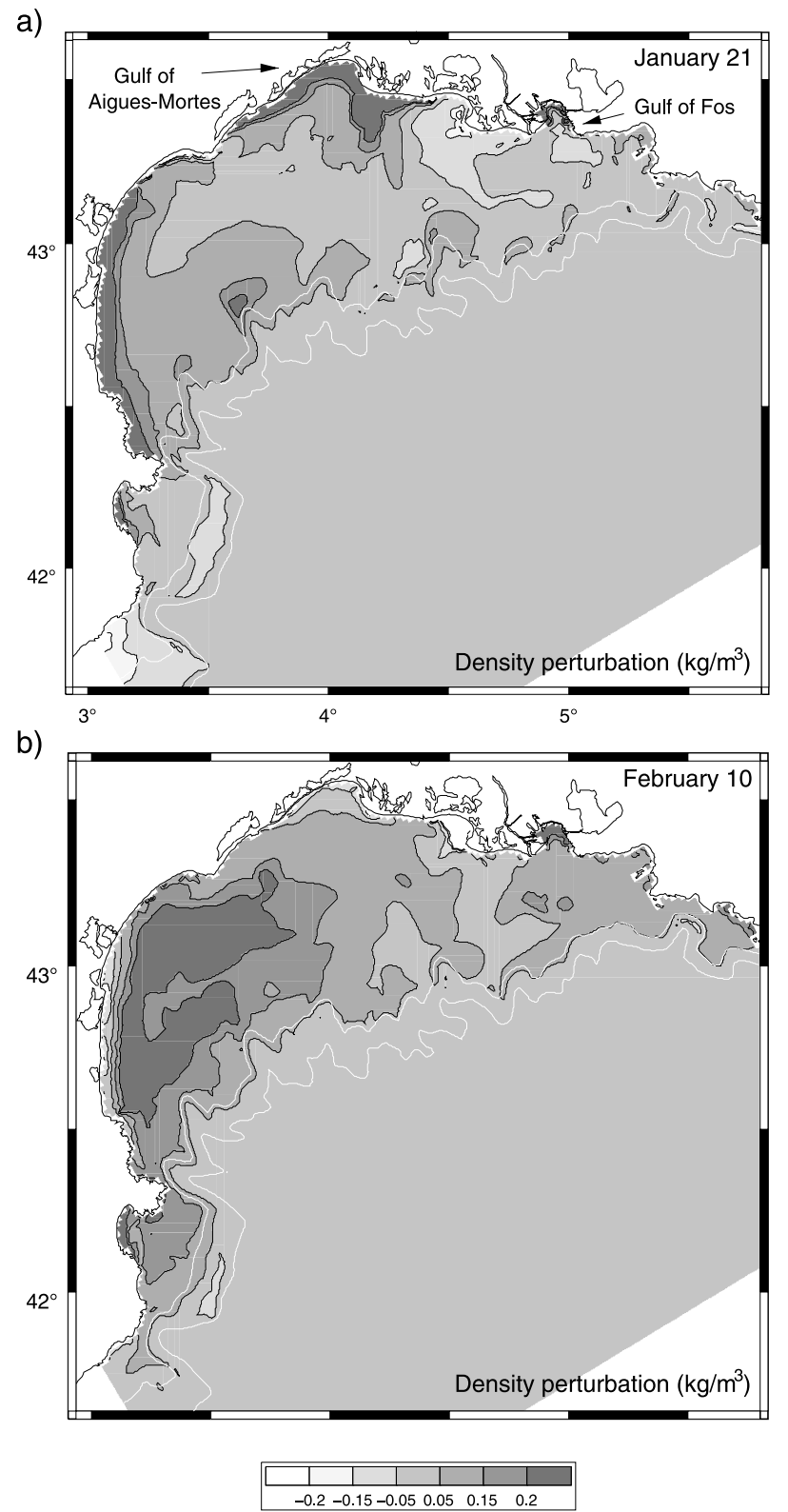

Figure 12. Near-bottom density perturbation $\left(\mathrm{kg} \mathrm{m}^{-3}\right)$ field (at each grid point, the horizontally averaged density at the considered depth was subtracted from the local density) for (a) 21 January and (b) 10 February 2004 at 0000 LT. This figure exhibits the different dense water formation areas: in early January, dense water was generated in shallow areas, while in February, after the input of river water along the coast, dense water formation occurred in the center of the shelf.

rivers of the Gulf of Lion on 4 December and the moderate Rhone flood in January (Figure 2d) significantly modified the thermohaline properties of the whole Gulf. The massive fresh water input before and during the dense water formation period together with the low intensity and fewer occurrences of cold northerly winds probably reduced the formation of dense water on the shelf and limited their cascading down the slope.
[54] In this section the processes of dense water formation and cascading during the first period of winter without the influence of marine storms are investigated. The second part of winter, marked by numerous marine storms, will be described in section 4.5.

[55] In January, four gusts of northerly winds triggered the formation of dense water along the coast in regions remote from river discharge (western coast, Gulf of AiguesMortes to the north and Gulf of Fos to the east) (Figures 12a and 13a). The cyclonic circulation on the western part of the shelf induced by such winds [Estournel et al., 2003] facilitated a southward transport of the dense water formed along the western coast. The overflow of dense water was then accelerated into the Cap Creus Canyon because of the narrowing of the shelf. When the wind stopped, density decreased along the coast (Figure 13b) because of lateral mixing and positive heat budget.

[56] In early February, coastal water density fell, especially on the northern inner shelf, as a result of the massive input of fresh water discharged during the second Rhone River flood (Figures 13b and 13c). This fresh water propagated southwestward along the coast under the influence of the alternation of low southwesterly and northerly winds. This flow accelerated the gravity-induced propagation of dense water, previously formed along the coast, toward the middle of the shelf. Consequently, density became higher on the outer shelf (Figure 13b). During the following moderate northerly wind episodes, the coldest water was still produced along the coast where surface heat losses associated with shallow water were the most efficient (Figure 13d). However, the fresh water supplied by rivers prevented a significant increase of coastal water density (Figures 13b and $13 \mathrm{c}$ ) and the densest water was mainly formed on the western mid shelf (Figure 12b). The increase of dense water volume was more pronounced between 50 and $100 \mathrm{~m}$ depth than in shallow waters along the coast $(\mathrm{H}<50 \mathrm{~m})$ (Figure 13e). The volume of dense water regularly increased in the middle of the shelf protected from river fresh water influence, until the late February marine storm (Figure 13b).

[57] Despite unfavorable conditions for dense water formation, dense water cascades occurred on the Gulf of Lion's slope during the study winter [Palanques et al., 2006]. The trajectories of modeled Lagrangian drifters (not shown) reveal that dense water formed during the first winter period reached its equilibrium level between 200 and $400 \mathrm{~m}$ depth. Most of the drifters deployed along the western coast plunged along the southern flank of the Cap Creus Canyon and then propagated southward along isobaths.

\subsection{Interaction Between Marine Storms and Dense Water Processes}

[58] This section aims at assessing how shelf-slope exchanges generated by marine storm-related processes are modulated by the dense water on the shelf and vice versa.

\subsubsection{Winter Marine Storms}

[59] The second part of the winter period was marked by the interaction between marine storm-induced downwelling and dense water cascading.

[60] In late February, an easterly wind blew for $3 \mathrm{~d}$ and reached a maximum speed of $16 \mathrm{~m} \mathrm{~s}^{-1}$. Moderate peaks of water discharge were recorded in all rivers of the Gulf. The temporal evolution of density, salinity, temperature and 

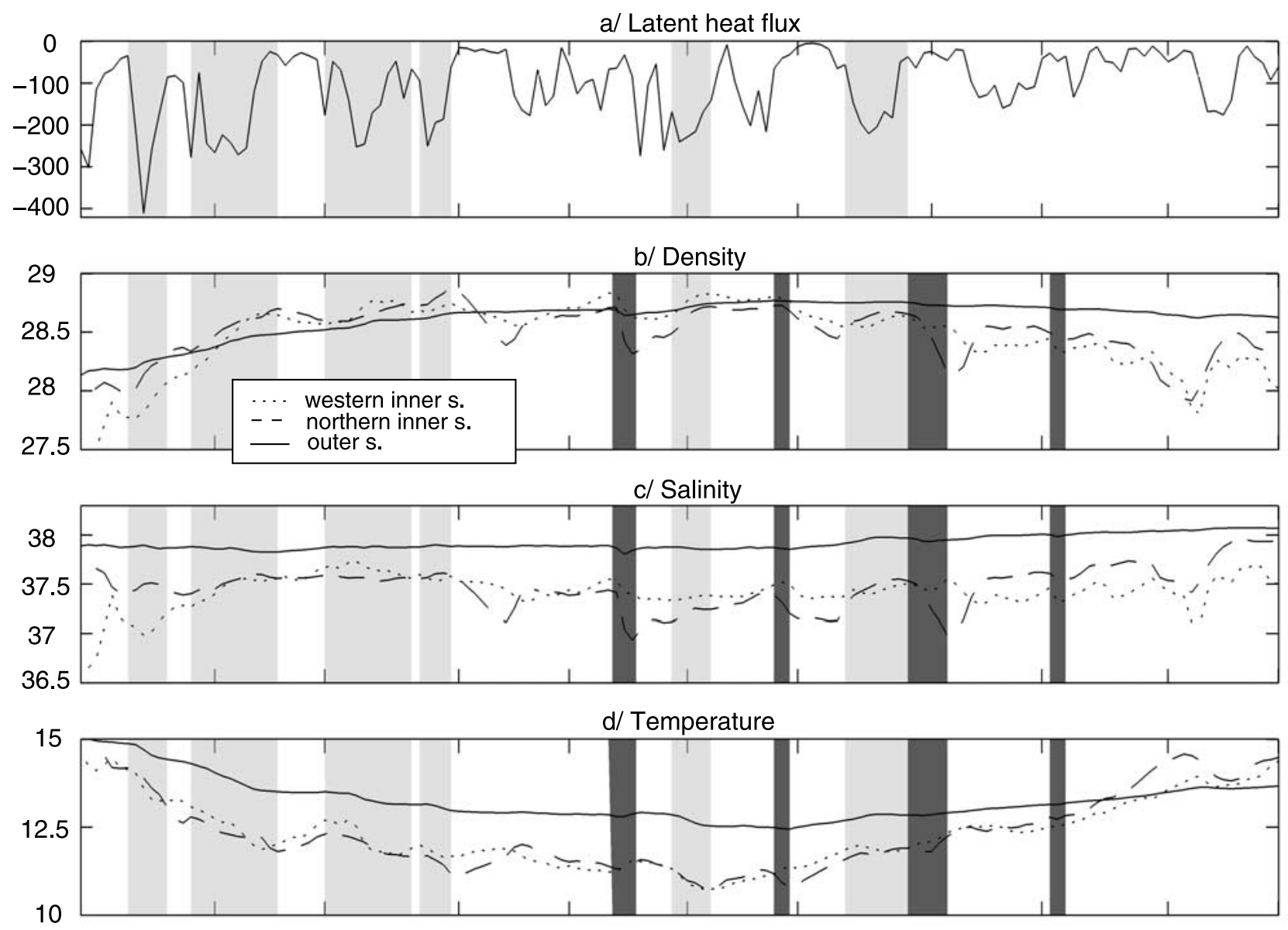

10

e/ Amount of shelf dense water

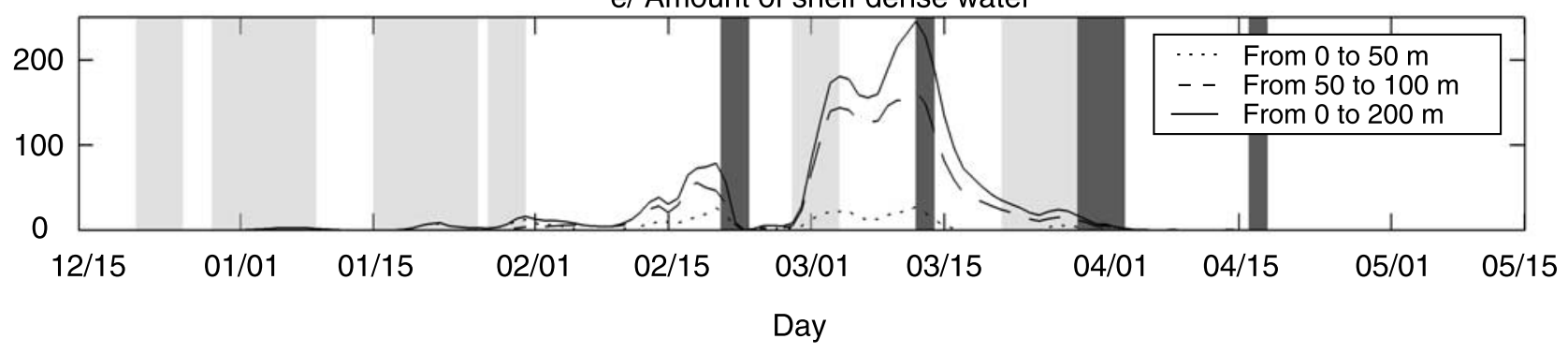

Figure 13. Time series of simulated (a) latent heat fluxes $\left(\mathrm{W} \mathrm{m}^{-2}\right)$, (b) near-bottom density $\left(\mathrm{kg} \mathrm{m}^{-3}\right)$, (c) near-bottom salinity, (d) near-bottom temperature $\left({ }^{\circ} \mathrm{C}\right)$, and (e) volume of shelf dense water (density $>$ $\left.28.8 \mathrm{~kg} \mathrm{~m}^{-3}\right)\left(\mathrm{km}^{3}\right)$. The latent fluxes were averaged over the Gulf of Lion's shelf, and the near-bottom density, salinity, temperature were averaged along the western and northern inner shelf dense water formation areas $(0<\mathrm{H}<50 \mathrm{~m})$ (dotted and dashed lines, respectively) and on the outer part of the shelf $(50<\mathrm{H}<200 \mathrm{~m})$ (solid lines). The light and dark shaded areas correspond to northerly wind and marine storm events, respectively.

downslope velocity recorded in the Cap Creus Canyon during this event is presented on Figure 6. A cooling of $1.6^{\circ} \mathrm{C}$, a salinity decrease of 0.5 unit and a downslope current up to $70 \mathrm{~cm} \mathrm{~s}^{-1}$ reflect the advection of shelf water into the canyon during the storm. The slight density decrease of $0.05 \mathrm{~kg} \mathrm{~m}^{-3}$ suggests that the storm-induced downwelling prevailed over the dense water cascading.

[61] In mid-March, cascading of relatively dense water $\left(29 \mathrm{~kg} \mathrm{~m}^{-3}<\right.$ density $<29.1 \mathrm{~kg} \mathrm{~m}^{-3}$ ) was observed (Figure 7) consecutively to a moderate marine storm. This cascading episode, characterized by a cooling of $0.8^{\circ} \mathrm{C}$, a salinity decrease of 0.2 unit and a down-canyon velocity of $20-40 \mathrm{~cm} \mathrm{~s}^{-1}$, persisted for almost one week.

[62] The simulated cyclonic circulation on the shelf induced by the February and March marine storms was similar to the December case (Figure 8) and facilitated the advection of dense water toward the shelf break, especially in the southwesternmost part of the Gulf. During these events, the relatively high density of the bottom shelf water intensified the storm-induced downwelling. In February, the near-bottom current was funneled into the canyons (Figure 14a) where it reached values up to $40 \mathrm{~cm} \mathrm{~s}^{-1}$ as 

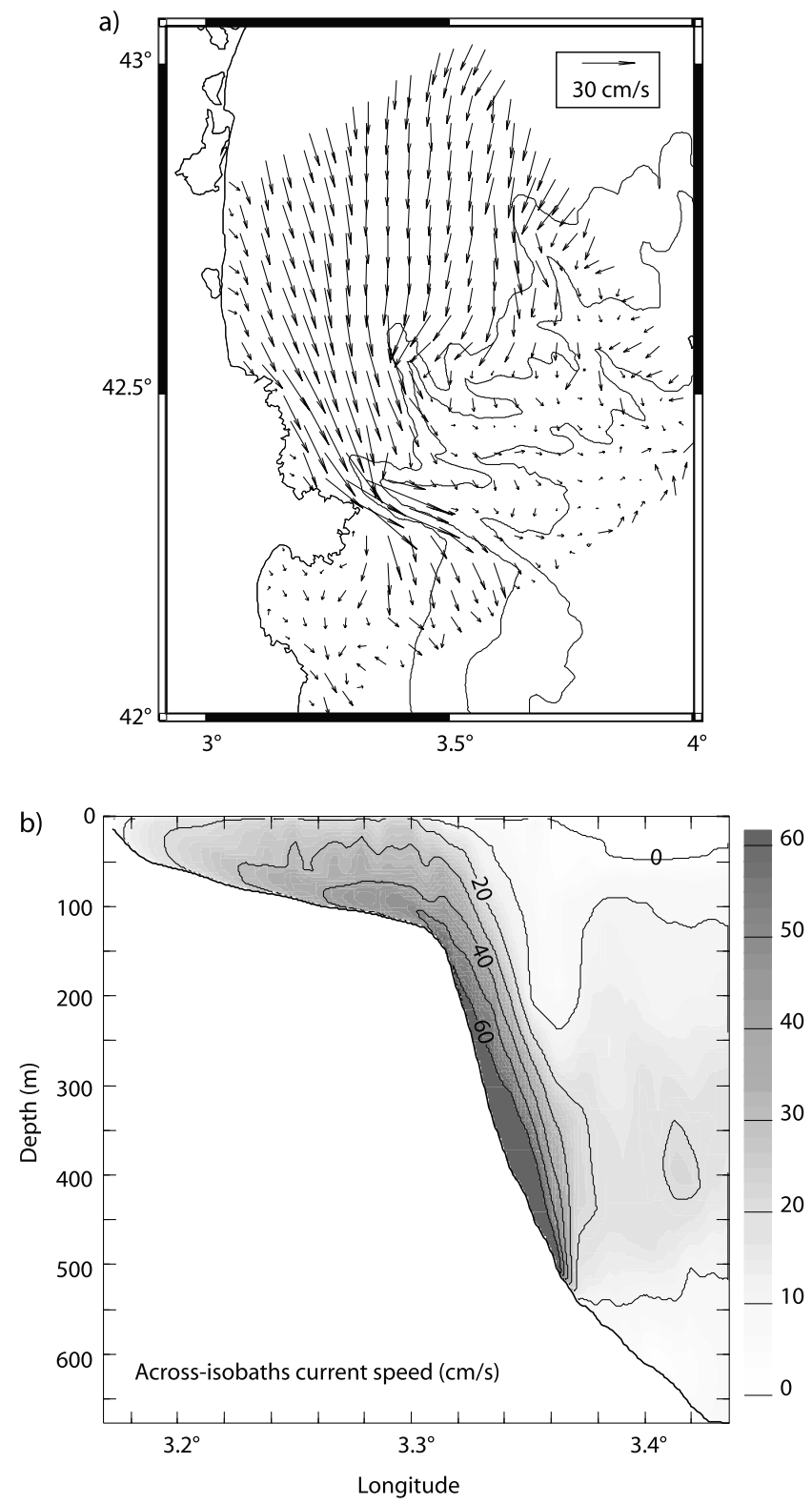

Figure 14. Simulated (a) near-bottom current and (b) vertical section of the across-isobaths component of the current $\left(\mathrm{cm} \mathrm{s}^{-1}\right)$ in the Cap Creus Canyon on 21 February 2004 at 0000 LT (see Figure 10a for section location), showing the acceleration of the current along the bottom of the Cap Creus Canyon with a markedly high velocity on the southern wall of the canyon. The offshore direction corresponds to positive values. Isobaths 150, 500 and 1000 are superimposed as lines on Figure 14a.

deep as $500 \mathrm{~m}$. In the Cap Creus Canyon, the strongest currents were located on the southern flank where dense water preferentially cascades. Figure $14 \mathrm{~b}$ emphasizes the fact that the transfer in the Cap Creus Canyon was confined near the bottom.

[63] During winter marine storms, the export was therefore enhanced near the bottom and was deeper than during the fall marine storm (Figure 14b versus Figure 9b).

\subsubsection{Influence of Marine Storms on Dense Water Formation and Cascading}

[64] During the northerly cold atmospheric events following the February marine storm, the simulated cooling of shelf water was maximum. Temperature along the coast was below $11^{\circ} \mathrm{C}$ whereas, on the outer shelf, it reached $12.5^{\circ} \mathrm{C}$ (Figure 13d, around $1 \mathrm{March}$ ). The volume of dense water strongly increased on the shelf (Figure 13e), essentially to the west, between 50 and $100 \mathrm{~m}$ deep, as salinity to the north had been reduced by the alongshore fresh water flow induced by the February marine storm (Figure 13b). A sensitivity test was performed by omitting the February storm in order to assess the impact of marine storms on the amount of dense water on the shelf. This test shows that the volume of the dense water present on the shelf during the early March northerly wind event would have been increased by a factor of $2-3$ along the coast and 1.5 on the whole shelf without the February storm (not shown).

[65] Marine storms had two opposite effects on dense water cascading. On the one hand, they favored the rapid cascading by facilitating the flushing of shelf water toward the shelf edge (see the sharp decrease of dense water volume after the February and March marine storms, Figure 13e) and on the other hand, by contributing to the renewal of shelf water and by concentrating fresh water against the coast where the efficiency of cold and dry winds in reducing temperature is the greatest, they delayed the subsequent densification of the shelf and then changed the cascading properties as the cascading rate and the equilibrium depth.

\subsection{Exchange Budget}

[66] Both marine storm-induced downwelling and dense water cascading were intensified in the southwesternmost canyons. In order to assess quantitatively the spatial variability of the shelf-slope exchanges, mass fluxes were computed at the southwest and northeast ends of the Gulf of Lion's shelf and through the seven submarine canyons where moorings were deployed. The segments following the shelf edge ( $\sim 200 \mathrm{~m}$ deep$)$ and those at the western and eastern ends of the shelf that were taken into account for the calculation of the fluxes are shown in Figure 15. Total fluxes were calculated over the whole water depth of the interface. Surface and bottom fluxes were computed for 40-m-thick surface and bottom layers, respectively. Finally, in order to ease comparisons with other sites, we computed exchange rates (i.e., the ratio of the mass flux by the associated segment length).

\subsubsection{Shelf Water Export During Marine Storms}

[67] We focused on the seawater exchanges induced by the two intense marine storms that occurred in December 2003 and February 2004.

[68] Figures 15a and 15b present the depth- and timeintegrated volumes of exported shelf water. Exchanges show the same spatial trend during the two storms. As expected, the major shelf water export for both events took place in the western part of the Gulf (western shelf; Cap Creus, Lacaze-Duthiers and Aude Canyons). The volume of exported shelf water was maximum in the Cap Creus Canyon, where it reached $25 \mathrm{~km}^{3}$ in early December and $91 \mathrm{~km}^{3}$ in late February. It then decreased progressively toward the center of the Gulf. Conversely, the eastern part of the Gulf was characterized by offshore water inflows, 
a) December storm (12 hours duration)

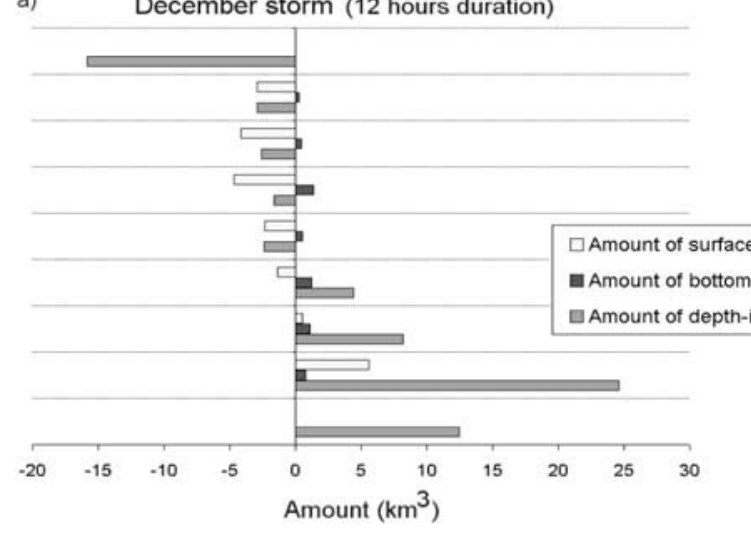

c)

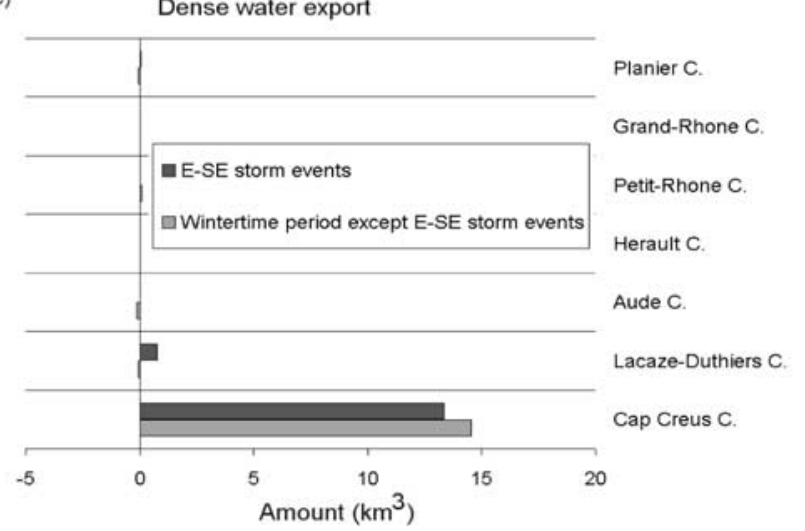

b) February storm (3 days duration)

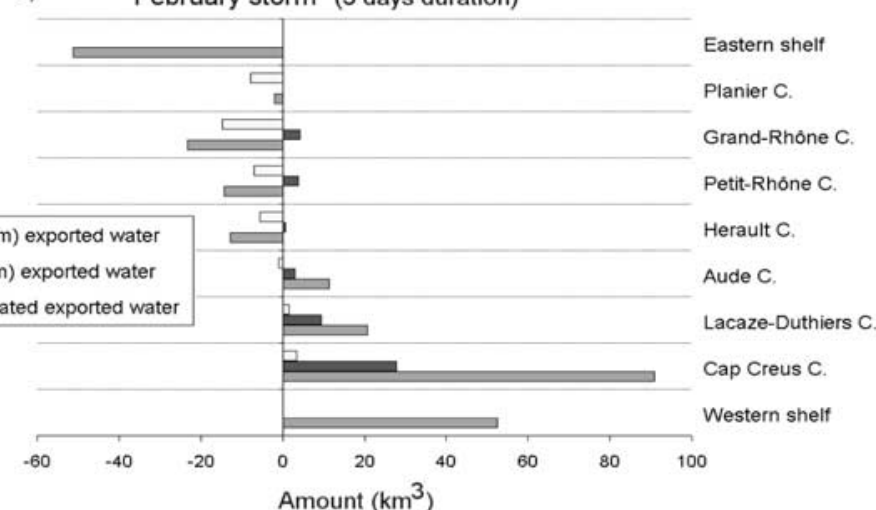

Figure 15. Amount of shelf water $\left(\mathrm{km}^{3}\right)$ exported during the (a) December 2003 (12 h duration) and (b) February 2004 ( $3 \mathrm{~d}$ duration) marine storms. The amount of exported shelf water was calculated over the whole water column $(\mathrm{H} \sim 200 \mathrm{~m}$ ), near the surface (in the upper $40 \mathrm{~m}$ ) (light grey) and near the bottom (in the lower $40 \mathrm{~m}$ ) (dark grey). (c) Amount of shelf dense water $\left(\mathrm{km}^{3}\right)$ exported during wintertime. The volume of dense water exported was calculated for winter storm periods (20-23 February and 11-15 March) (dark gray) and for winter period (from 1 January to 29 March) without marine storm events (light gray). The insert located in the bottom right corner indicates the segments across which the fluxes were calculated in thick black lines. This figure highlights the predominance of the southwesternmost part of the Gulf for shelf water export.

particularly at the eastern end of the shelf. The offshore water input in the eastern part induced by marine storms was thus globally balanced by an outflow in the western part. Nevertheless, it can be observed that the downwelling process caused shelf bottom water export in all submarine canyons.

[69] Differences of export during the fall and winter marine storms mainly related to buoyancy effects. During the December storm, shelf water export in the Cap Creus Canyon was higher in surface layers than near the bottom (see Figure 9b). Inversely, during the winter event, the downwelling was enhanced by the presence of dense water and the transfer essentially took place near the bottom (see Figure 14b). Despite a more intense transfer during the December storm, the longer duration of the February event induced a larger export.

\subsubsection{Shelf Dense Water Export}

[70] We established a budget of shelf dense water export during wintertime. We distinguished periods of marine storms from the rest of the period. Only shelf water with density higher than the average density of slope water was taken into account in the calculation. The average density of slope water increased from 28.79 to $28.85 \mathrm{~kg} \mathrm{~m}^{-3}$ during wintertime.

[71] During the winter marine storms (late February and mid-March), lasting 3-4 d each, the volume of exported dense water was of same order of magnitude than that found during the rest of the winter period extending over a 11-week period (Figure 15c). This reflects the magnitude of exchanges during such brief and intense marine storms. Furthermore, dense water export was clearly predominant in the Cap Creus Canyon where values were one order of magnitude higher than in the other canyons. The net flux in the Lacaze-Duthiers Canyon during the winter period without marine storms was negative because of intrusions of offshore water on to the shelf induced by northerly winds. Net exchanges in the other canyons were not significant. Sensitivity tests show that although the spatial variability of the exchanges remained unchanged, the value of fluxes is quite sensitive to the average density of slope water that conditions the computed export. If an increase and a decrease of this value by $0.01 \mathrm{~kg}$ $\mathrm{m}^{-3}$ are applied, the fluxes in the Cap Creus Canyon are 
decreased by a factor of $\sim 1.6$ and increased by a factor of $\sim 4$ for marine storms and $\sim 2$ for the rest of the period, respectively.

[72] By computing the overall shelf-slope fluxes of dense water over the Gulf and considering a length of the shelf edge interface of $160 \mathrm{~km}$, we estimated an average exchange rate of $0.06 \mathrm{~m}^{2} \mathrm{~s}^{-1}$ over the January to March period. A value of $0.49 \mathrm{~m}^{2} \mathrm{~s}^{-1}$ was calculated using the parameterization proposed by Huthnance [1995], $\mathrm{F}=(\mathrm{h} /$ $0.6 \mathrm{f})(\mathrm{g} \alpha / \rho \mathrm{Cp})^{2 / 3}\left(\mathrm{H}^{2} / \mathrm{Ws}\right)^{1 / 3}$ where $\mathrm{h}=80 \mathrm{~m}$ is the average water depth on the shelf, $f=10^{-4} \mathrm{~s}^{-1}$ the Coriolis parameter, $g=9.8 \mathrm{~m} \mathrm{~s}^{-2}$ the gravitational acceleration, $\alpha=$ $2.4 \times 10^{-4{ }^{\circ}} \mathrm{C}^{-1}$ the thermal expansion coefficient of the water, $\rho=1028.83 \mathrm{~kg} \mathrm{~m}^{-3}$ the average density of the water, $\mathrm{Cp}=4 \times 10^{3} \mathrm{~J} \mathrm{~kg}^{-10} \mathrm{C}^{-1}$ the specific heat of water, $\mathrm{H}=$ $125 \mathrm{~W} \mathrm{~m}^{-2}$ the heat loss from the surface and $\mathrm{Ws}=6.5 \times$ $10^{4} \mathrm{~m}$ the shelf width. The value resulting from this parameterization is one order of magnitude higher than the modeling result. This could be partly due to the fact that the influence of fresh water was not taken into account in this calculation. As the exchanges were highly localized in space and time, none of these average values reflects the intensity of the transfers observed and simulated in the western canyons during marine storms. In the Cap Creus Canyon, the simulated exchange rate reached mean values of $1.45 \mathrm{~m}^{2} \mathrm{~s}^{-1}$ during marine storms.

\section{Conclusions}

[73] On the basis of both field observations and model outputs, the shelf-slope exchanges in the Gulf of Lion were strongly affected by two physical mechanisms: dense water cascading and marine storm-associated processes.

[74] During fall, a strong marine storm provoked the transfer of shelf water in the southwestern Cap Creus area and produced downwelling in the submarine canyons. Nevertheless, the stratification of the water column at that time and, consequently, the lower density of the shelf waters limited the downwelling process and thus the export depth. Shelf water mainly flowed offshore near the surface in the Cap Creus Canyon and along shore toward the Spanish shelf.

[75] In early winter, vigorous and cold continental winds broke the stratification and eventually generated the formation of dense water along the coast. However, after a massive input of river water associated with low southerly and northerly winds, dense water was essentially generated between 50 and $100 \mathrm{~m}$ depth. Its cascades occurred in the canyons down to depths between 200 and $400 \mathrm{~m}$.

[76] Late winter and early spring were marked by unusual and frequent marine storms. Downwelling induced by marine storms were reinforced by the presence of dense shelf water that was thus flushed off the shelf mostly along the bottom of the Cap Creus Canyon.

[77] A budget of shelf water exported during the observation period reveals that marine storms produced exchange rates and fluxes higher than those obtained for dense water cascading alone. Marine storms appear as powerful mechanisms inducing substantial export of shelf water over short periods, equivalent to cascading episodes lasting several weeks. Nevertheless, it is difficult to dissociate the two mechanisms in terms of budget be- cause of their interactions. Marine storms first induced a lightening of water in preferential dense water formation areas (alongshore shallow areas) and also prevented a further densification of the existing dense shelf water by flushing the shelf. Therefore they limited the depth of export. Conversely, the presence of dense water strengthened the intrusion of the storm-induced downwelling on the deeper part of the slope.

[78] The work presented in this paper highlights the major role of marine storms on water renewal on the shelf. As marine storms promote large resuspension along the coast [Ferré et al., 2005; Guillén et al., 2006], we can expect strong particulate and dissolved matter export during these brief and particularly energetic events, especially in the winter season where the transfer is confined near the bottom. Finally, the water export induced by marine storms could have an important effect on biogeochemical processes. In particular, storms could be responsible for the export of dissolved and particulate organic matter resulting from blooms that occur generally at the end of winter and in early spring.

[79] Acknowledgments. This study was supported by the EUROSTRATAFORM Project funded by the EU (EVK3-CT-2002-00079, EU Fifth Framework Program: Energy, Environment and Sustainable Development). Part of this work was funded by the EU in the framework of FP6 GMES activities according the terms of the contract SST4-CT-2005-012336 (INSEA project). The authors thank the captain and the crew of R/V Tethys II from CNRS-INSU for their assistance. We gratefully acknowledge Albert Palanques and Antoni Calafat for the current data. We thank Météo-France for the ALADIN model outputs. We are grateful to the Compagnie Nationale du Rhône, the Banque HYDRO, the Agència Catalana de l'Aigua and P. Puig from ICM for providing river discharge; P.-Y. Valantin and C. Tissot from the Service Maritime et de Navigation du Languedoc Roussillon for the wave and sea level data; F. Bourrin for the processing of the coastal station measurement; and L. Roblou from Laboratoire d'Aérologie for the post data analyses. We acknowledge the MFSTEP program for OGCM outputs. We warmly thank the computer scientists of the Laboratoire d'Aérologie for their assistance and members of the POC group (http://poc.obs-mip.fr) for fruitful discussions. C.U. benefits from Lavoisier fellowship.

\section{References}

Albérola, C., and C. Millot (2003), Circulation in the French Mediterranean coastal zone near Marseilles: The influence of wind and the Northern Current, Cont. Shelf Res., 23, 587-610.

Arakawa, A., and M. J. Suarez (1983), Vertical differencing of the primitive equations in sigma coordinates, Mon. Weather Rev., 111, 34-45.

Auclair, F., P. Marsaleix, and C. Estournel (2000), Sigma coordinate pressure gradient errors: Evaluation and reduction by an inverse method, J. Atmos. Oceanic Technol., 17, 1348-1367.

Auclair, F., P. Marsaleix, and C. Estournel (2001), The penetration of the Northern Current over the Gulf of Lion (Mediterranean) as a downscaling problem, Oceanol. Acta, 24, 529-544.

Auclair, F., C. Estournel, P. Marsaleix, and I. Pairaud (2006), On coastal ocean embedded modeling, Geophys. Res. Lett., 33, L14602, doi:10.1029/2006GL026099.

Béthoux, J. P., X. Durrieu de Madron, F. Nyffeler, and D. Tailliez (2002), Deep water in the western Mediterranean: peculiar 1999 and 2000 characteristics, shelf formation hypothesis, variability since 1970 and geochemical inferences, J. Mar. Syst., 33-34, 117-131.

Blumberg, A. F., and G. Mellor (1987), A description of a three dimensional coastal circulation model, in Three-Dimensional Coastal Ocean Model, Coastal and Estuarine Sci. Ser., vol. 4, edited by N. Heaps, pp. 1-16, AGU, Washington, D. C.

Bougeault, P., and P. Lacarrère (1989), Parameterization of orographyinduced turbulence in a meso-beta scale model, Mon. Weather Rev. 117, $1872-1890$

Canals, M., P. Puig, X. Durrieu de Madron, S. Heussner, A. Palanques, and J. Fabrès (2006), Flushing submarine canyons, Nature, 444, 354-357. Conan, P., and C. Millot (1995), Variability of the northern current off Marseilles, western Mediterranean sea, from February to June 1992, Oceanol. Acta, 18(2), 193-205. 
Dufau-Julliand, C., P. Marsaleix, A. Petrenko, and I. Dekeyser (2004), Three-dimensional modeling of the Gulf of Lion's hydrodynamics (northwest Mediterranean) during January 1999 (MOOGLI3 Experiment) and late winter 1999: Western Mediterranean Intermediate Water's (WIW's) formation and its cascading over the shelf break, J. Geophys. Res., 109, C11002, doi:10.1029/2003JC002019.

Durrieu de Madron, X., V. Zervakis, A. Theocharis, and D. Georgopoulos (2005), Comments on "cascades of dense water around the world ocean," Prog. Oceanogr., 64(1), 83-90.

Estournel, C., V. Kondrachoff, P. Marsaleix, and R. Vehil (1997), The plume of the Rhône: Numerical simulation and remote sensing, Cont. Shelf Res., 17, 899-924.

Estournel, C., P. Broche, P. Marsaleix, J. L. Devenon, F. Auclair, and R. Vehil (2001), The Rhône river plume in unsteady conditions: numerical and experimental results, Estuarine Coastal Shelf Sci., 53, 25-38.

Estournel, C., X. Durrieu de Madron, P. Marsaleix, F. Auclair, C. Julliand, and R. Vehil (2003), Observation and modeling of the winter coastal oceanic circulation in the Gulf of Lion under wind conditions influenced by the continental orography (FETCH experiment), J. Geophys. Res., 108(C3), 8059, doi:10.1029/2001JC000825.

Estournel, C., V. Zervakis, P. Marsaleix, A. Papadopoulos, F. Auclair, L. Perivoliotis, and E. Tragou (2005), Dense water formation and cascading in the Gulf of Thermaikos (North Aegean) from observations and modelling, Cont. Shelf Res., 25, 2366-2386, doi:10.1016/ j.csr.2005.08.014.

Ezer, T., and G. L. Mellor (2004), A generalized coordinate ocean model and a comparison of the bottom boundary layer dynamics in terrainfollowing and in z-level grids, Ocean Modell., 6, 379-403.

Ferré, B., K. Guizien, X. Durrieu de Madron, A. Palanques, J. Guillén, and A. Grémare (2005), Fine sediment dynamics study during a winter storm in the Gulf of Lion shelf (NW Mediterranean), Cont. Shelf Res., 25(1920), 2410-2427.

Fieux, M. (1974), Formation d'eaux denses sur le plateau continental du Golfe du Lion, in Processus de Formation des Eaux Océaniques Profondes, Colloq. Int. CNRS, 215, 165-174.

Fofonoff, N. P., and R. C. Millard (1983), Algorithms for computation of fundamental properties of seawater, UNESCO Rep., 44, 15-24.

Gatti, J., A. Petrenko, J.-L. Devenon, Y. Leredde, and C. Ulses (2006), The Rhone river dilution zone present in the northeastern shelf of the Gulf of Lions in December 2003, Cont. Shelf Res., 26, 1794-1805.

Geernaert, G. L. (1990), Bulk parameterizations for the wind stress and heat fluxes, in Surface Waves and Fluxes, vol. I, Current Theory, edited by G. L. Geernaert and W. J. Plant, pp. 91-172, Springer, New York.

Guarracino, M., B. Barnier, P. Marsaleix, X. Durrieu de Madron, A. Monaco, K. Escoubeyrou, and J.-C. Marty (2006), Transfer of particulate matter from the northwestern Mediterranean continental margin: Variability and controlling factors, J. Mar. Res., 26, 195-220.

Guillén, J., F. Bourrin, A. Palanques, X. Durrieu de Madron, P. Puig, and R. Buscail (2006), Sediment dynamics during "wet" and "dry" storm events on the Têt inner shelf (SW Gulf of Lions), Mar. Geol., 234, $129-142$

Guizien, K., T. Brochier, J.-C. Duchêne, B.-S. Koh, and P. Marsaleix (2006), Dispersal of owenia fusiformis larvae by wind-driven currents: Turbulence, swimming behaviour and mortality in a three-dimensional stochastic model, Mar. Ecol. Prog. Ser., 311, 47-66.

Heggelund, Y., F. Vikebø, J. Berntsen, and G. Furnes (2004), Hydrostatic and non-hydrostatic studies of gravitational adjustment over a slope, Cont. Shelf Res., 24, 2133-2148.

Heussner, S., X. Durrieu de Madron, A. Calafat, M. Canals, J. Carbonne, N. Delsaut, and G. Saragoni (2006), Spatial and temporal variability of downward particle fluxes on a continental slope: Lessons from an 8-yr experiment in the Gulf of Lions (NW Mediterranean), Mar. Geol., 234, $63-92$.

Huthnance, J. M. (1995), Circulation, exchange and water masses at the ocean margin: The role of physical processes at the shelf edge, Prog. Oceanogr, 35, 353-431.

Ivanov, V. V., G. I. Shapiro, J. M. Huthnance, D. L. Aleynik, and P. N. Golovin (2004), Cascades of dense water around the world ocean, Prog. Oceanogr., 60, 47-98.

Johns, B., and T. Oguz (1987), Turbulent energy closure schemes, in ThreeDimensional Coastal Ocean Model, Coastal and Estuarine Sci. Ser. vol. 4, edited by N. Heaps, pp. 17-39, AGU, Washington, D. C.

Johns, B., P. C. Sinha, S. K. Dube, U. C. Mohanty, and A. D. Rao (1983), Simulation of storm surges using a three-dimensional numerical model: An application to the 1977 Andhra cyclone, Q. J. R. Meteorol. Soc., 109, $211-224$.

Lapouyade, A., and X. Durrieu de Madron (2001), Seasonal variability of the advective transport of particulate matter and organic carbon in the Gulf of Lion (NW Mediterranean), Oceanol. Acta, 24(3), 295-312.
Letellier, T. (2004), Etude des ondes de marée sur les plateaux continentaux, PhD thesis, Univ. Toulouse III-Paul Sabatier, Toulouse, France.

Liu, J. T., H.-L. Lin, and J. J. Hung (2006), A submarine canyon conduit under typhoon conditions off southern Taiwan, Deep Sea Res., Part I, 53, $223-240$.

Marsaleix, P., F. Auclair, and C. Estournel (2006), Considerations on open boundary conditions for regional and coastal ocean models, J. Atmos. Oceanic Technol., 23, 1604-1613.

MEDOC Group (1970), Observation of formation of deep water in the Mediterranean Sea, 1969, Nature, 227, 1037-1040.

Mellor, G. L. (2003), Guide for a three-dimensional, primitive equation, numerical ocean model (June 2003 version), 53 pp., Program in Atmos. and Ocean. Sci., Princeton Univ., Princeton, N. J.

Mellor, G. L., S. Häkkinen, T. Ezer, and R. Patchen (2002), A generalization of a sigma coordinate ocean model and an intercomparison of model vertical grids, in Ocean Forecasting: Conceptual Basis and Applications, edited by N. Pinardi and J. Woods, pp. 55-72, Springer, Berlin.

Mienert, J., et al. (2004), Overview of recent, ongoing and future investigations on the dynamics and evolution of European margins, Oceanography, 14(4), 17-33.

Millot, C. (1990), The Gulf of Lions' hydrodynamics, Cont. Shelf Res., 19, $885-894$.

Monaco, A., T. Courp, S. Heussner, J. Carbonne, S. W. Fowler, and B. Deniaux (1990), Seasonality and composition of particulate fluxes during ECOMARGE-I, western Gulf of Lion, Cont. Shelf Res., 10(9-11), 959-987.

Palanques, A., X. Durrieu de Madron, P. Puig, J. Fabres, J. Guillen, C. Antoni, M. Canals, and J. Bonnin (2006), Suspended sediment fluxes and transport processes in the Gulf of Lion submarine canyons. The role of storms and dense water cascading, Mar. Geol., 234, 41-63.

Person, R. (1974), Un exemple de descente des eaux superficielles du plateau continental dans un canyon du Golfe du Lion, in Processus de Formation des Eaux Océaniques Profondes, Colloq. Int. CNRS, 215, $175-189$.

Petrenko, A., Y. Leredde, and P. Marsaleix (2005), Circulation in a stratified and wind-forced Gulf of Lions, NW Mediterranean Sea: In-situ and modeling data, Cont. Shelf Res., 25, 7-27.

Pietrzak, J., J. B. Jakobson, H. Burchard, H. Vested, and O. Petersen (2002), A three-dimensional hydrostatic model for ocean modelling using a generalized topography following coordinate system, Ocean Modell., 4 , $173-205$.

Poirel, A., G. Carrel, and J. M. Olivier (2001), Illustration de la complémentarité des chroniques environnementales dans l'étude d'un hydrosystème fluvial: Régime thermique et peuplement piscicoles du Rhône, paper presented at Workshop on Activities in the Catchement Area and Water Quality, Agence de l'Eau Rhône Méditerranée Corse, Lyon, France.

Reffray, G., P. Fraunié, and P. Marsaleix (2004), Secondary flows induced by wind forcing in the Rhône region of freshwater influence, Ocean Dyn., $54,179-196$

Shapiro, G., and A. Hill (1997), Dynamics of dense water cascades at the shelf edge, J. Phys. Oceanogr., 27, 2381-2394.

Skliris, N., G. Lacroix, and S. Djenidi (2004), Effects of extreme meteorological conditions on coastal dynamics near a submarine canyon, Cont. Shelf Res., 24, 1033-1045.

Sternberg, R. W., and D. A. McManus (1972), Implications of sediment dispersal from long-term, bottom-current measurements on the continental shelf of Washington, in Shelf Sediment Transport: Processes and Pattern, edited by D. J. P. Swift, D. B. Duane, and O. H. Pilkey, pp. 181-194, Dowden, Hutchinson and Ross, Stroudsburg, Pa.

Ulses, C., C. Grenz, P. Marsaleix, E. Schaaff, C. Estournel, S. Meulé, and C. Pinazo (2005), Circulation in a semi enclosed bay under the influence of strong fresh water input, J. Mar. Syst., 56, 113-132.

Vilibić, I., B. Grbec, and N. Supić (2004), Dense water generation in the north Adriatic in 1999 and its recirculation along the Jabuka Pit, Deep Sea Res., Part I, 51, 1457-1474.

Vitorino, J., A. Oliveira, J. M. Jouanneau, and T. Drago (2002), Winter dynamics on the northern Portuguese shelf. Part 1: Physical processes, Prog. Oceanogr., 52, 129-153.

J. Bonnin and X. Durrieu de Madron, Centre de Formation et de Recherche sur l'Environnement Marin, Centre National de la Recherche Scientifique-Université de Perpignan, F-66860 Perpignan, France.

C. Estournel, P. Marsaleix, and C. Ulses, Pole d'Océanographie Côtière, Laboratoire d'Aérologie, UMR 5560, Centre National de la Recherche Scientifique-Université Paul Sabatier, 14 Avenue E. Belin, F-31400 Toulouse, France. (ulsc@aero.obs-mip.fr) 